\title{
Osmanlı Döneminde Latin Harfleriyle Türkçe Yazılan Eserler ve Yazarları
}

\author{
YUNUS INCE* • BAYRAM AKÇA**
}

\begin{abstract}
ÖZ
Erken modern dönemde (1450-1750) Osmanlı Devleti ile ekonomik, siyasi ve askerî ilişkileri olan Avrupa toplumlarında Osmanlılara yönelik bir korkunun varlığı bilinmektedir. Türklerle askerî alanda baş edememekten kaynaklanan bu korku, XVI. yüzyılın sonlarından itibaren Osmanlı merakına dönüşmüştür. Bu da giyimde, müzikte ve sanatta Osmanlıyı taklit şeklinde tezahür etmiştir. Türkçe öğrenme arzusu da bunun doğal yansımalarından birisidir. Türkçenin bu dönemde bir lingua franca, yani ortak dil olarak benimsenmesi dikkat çekicidir. Bu makalede, Osmanlı asırlarında Batılılar tarafindan Latin harfleriyle Türkçe yazılan metinler üzerinde durulacak, ancak metinlerin dil araştırmalarında nasıl kullanılabileceği konusuna girişilmeyecektir. Türk korkusunun ve bunun doğurduğu Turquerie akımının Avrupa'da Türkçe öğrenme merakına etkileri ve bunun sonuçları tartışılacaktır. Türkçe öğrenmeyi ve yazmayı belirleyen dinamikler, Türkçe metinler ve ilgili eserler esas alınarak ortaya konulacaktır. Değerlendirmede metin yazarlarının milliyeti, Türkçe öğrenme nedenleri, eserlerin yazılı̧̧ tarihleri de göz önünde bulundurulmuştur. Ayrıca matbaanın Latince dışındaki dillerin -bu arada Türkçenin öğrenilmesindeki etkisine de değinilmiştir. Çalışmanın erken modern dönemdeki Türkçe algısını temel sebepleriyle ortaya koyması beklenmektedir.
\end{abstract}

Anahtar sözcükler: Türkçe, Latin alfabesi, matbaa, erken modern dönem, lingua franca

* Yrd. Doç. Dr. Muğla Üniversitesi Edebiyat Fakültesi Tarih Bölümü, E-posta: yunusince@yandex.com

** Prof. Dr., Muğla Üniversitesi, Tarih Bölümü/MUĞLA

E-posta: abayram@mu.edu.tr 


\section{Giriş}

Y

azı, Sümerler tarafindan MÖ 3200 yıllarında Aşağı Mezapotamya'da bulunmuştur (Bottéro 2012:110-111). Günümüz Türkçesinde kullanılan alfabe terimi, Fransizca alphabet kelimesinden gelmektedir. Bu kelime de eski Yunancadaki ilk iki harf olan alfa $(\mathrm{A} \alpha)$ ve beta $(\mathrm{B} \beta)$ harflerinin okunuşundan gelir. Genel olarak bir yazı sisteminde kullanılan ilk birkaç harfin telaffuzu alfabe olarak kabul edilir. Alfabe terimi yerine Osmanlı döneminde elifba (' ,ب), günümüzde abece (A, B, C) denmesi de ilk harflerin telaffuzundan ileri gelir.

Tarih boyunca bütün kavim/milletler gibi Türkler de birbirinden oldukça farklı alfabeler kullanmışlardır. Yeni bir medeniyet dairesine ya da yeni bir kültürle etkileşime giren bir milletin o medeniyetin/kültürün dilinden çok etkilendiği hatta o medeniyetin/kültürün alfabesini de benimsediği malumdur. Birbirinden farklı medeniyetlerle/kültürlerle etkileşime giren Türkler de zamam zaman bunların alfabelerini kullanmışlardır. Tarihî süreçte Çin ideogramlarının; Göktürk, Manihey, Soğd, Uygur, Tibet, Süryani, İbrani, Grek, Ermeni, Brahmî ve Kril alfabelerinin Türkler tarafindan kullanıldığ 1 bilinmektedir (Tekin 1997; Balta 2014; Pamukciyan 2002; Hazai 1967: 143155).

Türkler, İslamiyet'i kabul ettikten sonra bu yeni medeniyetin alfabesini de benimsedikleri için Osmanlı Devleti döneminin resmî dili Türkçe, Arap

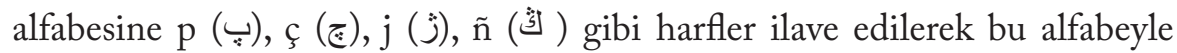
yazılmıştır. Osmanlı Devleti'nin son dönemlerinde Batılılaşma gayretleriyle yeni bir medeniyet dairesiyle temasa geçilmiş ve bu nedenle bazı mütefekkirler, Arap harfleri yerine Latin alfabesinin kullanılmasını savunmuşlardır. Ancak bu düşünceler öneri olmaktan öteye gitmemiştir. Cumhuriyetin ilanından sonra Arap harfleri yerine Latin harflerinin kullanılması öngörülmüş ve bu husus "Türk Harflerinin Kabul ve Tatbiki Hakkında Başvekâletten Mevrut 1/266 Numaralı Kanun

Layihası" olarak Türkiye Büyük Millet Meclisi gündemine gelmiştir (TBMM Zabıt Ceridesi, Devre 3, İctima 2, V, 1 Teşrinisâni 1928: 1-13). Görüsmeler neticesinde 1 Kasım 1928 taribinde 1353 saynl "Türk Harflerinin Kabul ve Tatbiki Hakkında Kanun"un kabulüyle W, Q ve X gibi harfler dışındaki Latin harfleri, Arap harfleri yerine ve Türk harfleri olarak kabul edilmistir (Türkiye Cumburiyeti Resmî Gazetesi, 3 Teşrînievvel 1928, 1030, Kanun nu.: 1353: 5998-6003). Ancak Latin harflerinin Türk harfleri olarak kabulünden önce de Latin harfleriyle Türkşe yazıldığı bilinmektedir. 


\section{BATILILARIN TÜRKÇE YAZMA NEDENLERİ}

\section{Türk Korkusu ve Turquerie Akımı}

Tarih boyunca rakiplerine üstünlüklerini kabul ettiren devlet ve topluluklar, onların üzerinde korku ve merak uyandırdıkları bilinmektedir. Osmanlıların 14. yüzyılın ikinci yarısından itibaren önce Rumeli'ye yerleşmeleri, ardından Avrupa içlerine doğru ilerlemeleri neticesinde bu coğrafyada bir Türk korkusu ortaya çıkmıştır. Korku olgusu, hem korkunun kaynağı olan Osmanlılar hem de korkunun egemen olduğu Avrupalılar tarafindan kullanılmıştır. Osmanlılar korkuyu askerî seferlerinde kolaylaştırıcı bir faktör olarak değerlendirirken, Avrupalılar ise kamuoyunda Türkler hakkında olumsuz bir kanaat oluşturmak ve halkın İslam'ı kabul etmesine engel olmak Türk korkusunu kullanmışlardır. Bu propagandalarda din adamları tarafindan verilen vaazlardan, konuyla ilgili broşür ve kitaplardan ve gazetta lardan yararlanmışlardır. Bu amaçla, sadece Türk korkusunu konu edinen kitapçıklar (büchlein) yayınlanmıştır. Nitekim 1522 gibi erken bir dönemde bir Türkenbüchlein yayınlanmıştır (Kumrular 2012: 43-45). Benzer nitelikteki yayınlarla Türk korkusu daha geniş kitlelere yayılmışıtır.

İstanbul'un Osmanlılar tarafından fethi Türk korkusunun ortaya çıkmasında dönüm noktalarından birisini teşkil eder. Bunun yaygınlaşmasını isteyen propagandacılar "Türk timsalini şeytanlaştırmak için sıkı bir uğraş içerisine girdiler. Onların korku salan kampanyası genellikle başarılı olsa da fetibçilere dönük Avrupa merakın tam bastıramadı. Bu ilgi Osmanl toprakların gezmiş seyyablarn yaymlanan anlatımlarıla ve 16. yüzyıl ortalarmdan itibaren Osmanl giyimi hakkında bilgi veren resimli kostüm kitaplarıyla kısmen tatmin edildi." Osmanlıların 1683 yılında Viyana önlerinde bozguna uğraması bu "büyük korkuyu" kısmen hafifletmiştir. XVI. yüzyılın sonlarından itibaren bu korkunun yerini merak almaya başlamışırı. Antoine Galland tarafindan çevrilen Bin Bir Gece Masallarinın ilk ciltleri 1704 yılında yayınlanmıştır. Esasen bu masallar, doğrudan Osmanlı ile ilgili değildi. Bu masal derlemesinde çok az Osmanlı masalı vardı. Ancak yine de bu masallarda tasvir edilen egzotik dünya, Osmanlı Devleti ve dolayısıyla da Türklerle ilişkilendirildi. Daha sonra Osmanl1-Türk yaşamına dair Avrupa'da büyük oranda hayale dayanan bir sanat akımı başladı. Bu akımın etkisiyle bazı ünlülerin Osmanlı tarzı giyimli portrelerini yaptırdığ görülmekteydi. Söz konusu modaya uygun olarak dikilen bir balo kostümü, bir porselen eser, bazen de bir çadır Avrupa'da talep gören nesneler hâline geldiği gibi (Williams 2015: 7-12; Van Mour: 1714) bu akımının etkili olduğu dönemde tarihî olayları konu edinen pek çok tiyatro ve müzik eseri icra edildi (Meyer 1974: 474-488). 
Osmanlı Devleti 1683 yılında Viyana önlerinde ikinci kez mağlup oldu. Ancak Osmanlı ordusunun yanında getirdiği kahve, muhtelif elbiseler, el yazması eserler ve bazı müzik aletleri Avrupalılar tarafindan rağbet görmeye başladı. Aslında burada Avrupa'nın aldığı şey kahve, elbiseler, müzik ya da el yazması eserler değil Turquerie adlı bir moda akımıydı. Turquerie akımının yaygınlık kazanmasında II. Viyana Kuşatmasına kadar kıta Avrupası'nda hüküm süren Türk korkusunun bitmesi etkili oldu (Bevilacqua vd. 2013: 75118). XVIII. yüzyıl sonlarına doğru Turquerie modasının etkisi oldukça azaldı (Alarslan 2005: 151-512). Türk korkusu ve ardından gelen Turquerie modası, Avrupa kökenli bazı kişilerin Türkçe öğrenmelerinde ve öğrendiklerini Latin harfleriyle yazmalarında önemli bir rol oynadı.

Osmanlı Devleti'nin hâkimiyet kurduğu coğrafya, eski dünya üzerinde oldukça büyük bir yer kaplamaktaydı. Osmanlı coğrafyasının genişliği kadar, Osmanlı askerî gücünün uzun süre rakipleri üzerinde büyük baskı unsuru olması sebebiyle Osmanlı Devleti'nin güçlü olduğu dönemlerde Türkçe, devrin küresel dili (lingua franca) hâline geldi (Akar 2014: 6063). Akdeniz coğrafyasında farklı kültürlerin, milliyetlerin en önemli iletişim araçlarından biri Türkçe oldu. Nitekim Kanuni Sultan Süleyman zamanında Osmanlı sultanının cihanşümul otoritesini dünyaya duyurmak için Venedik'te bir atölyede yaptırılan bir haritayı hazırlayan Hacı Ahmed, kendisi Arap olmasına rağmen bu haritayı Türkçe hazırlama nedenini şöyle ifade etmişti: "Efendimin buyruğuna uyarak, bu çeviriyi elimden geldiğince Türkşe olarak yazdım, çünkü dünyay yöneten bu dildir (Ve bu tercüme kadîr oldugım kadar agamun emr ile Türk diline yazdum zirâ kîm bu dil dünyâda gayetile hükm ider)" (Casale 2014:105).

Türkçede karışıklığı belirtmek için kullanılan "Arap saçına dönmek” deyimine benzer biçimde "Ben Türkşe mi konuşuyorum?" şeklinde İtalyancada üretilen deyim, anlaşılmaz bir durumu tanımlamada hâlen kullanılmaktadır (Carretto 1992: 1). Oysa bugünün İtalyan'ının karışık/anlaşılmaz bir dil olarak düşündüğü Türkçe, vaktiyle pek çok İtalyan şehir cumhuriyeti tebaası için öğrenilmesi özellikle arzu edilen bir dildi.

\section{Latin Harfli İlk Türkçe Metinler}

Tarihî süreçte farklı milletlerden birçok kişi, Latin harfleriyle Türkçe yazmıştır. Bunlardan İtalyanların konumuz açısından ayrı bir yeri vardır. Latin alfabesiyle Türkçe yazılan ilk metin olan Codex Cumanicus (Codex Cumanicus Bibliothecae ad Templum Divi Marci Venetiarum 1880) 
adlı Kuman Türklerinin diline dair eserin İtalyan tüccarlar ile Fransisken tarikatına mensup Alman rahipler vasıtasıla bir araya getirilen derleme bir eser olduğu bilinmektedir (Toparlı vd. 2007: V).

Codex Cumanicus'tan sonra ilk Latin harfli Türkçe ifadeler, Johannes Schiltberger (doğ. 1380/1 - öl. 1440) adlı bir Alman'ın 1427 yllında yazdığı, 1460 yılında Ausburg'da basılan esaret hatıralarında geçmektedir. Schiltberger, hatıratında bazı şahıs ve yer isimleri dışında, İslamiyet'e dair bazı dinî ibareleri aktarırken Türkçe yazmayı tercih etmiştir: "La il lach illallach/Lâ ilâhe illallah" ve "Thary wirdur, messe chulochur, maria(lara) (kara) baschidur machmet kassuldur. / Tanr birdir, Mesih (İsa) kuludur, Meryem kızıdır, Muhammed en büyük peygamberdir" şeklindeki sözler bunlardan birkaçıdır. Aynı şekilde Hristiyanlıktaki Pater Noster (Babamız) adlı bir duadan bahsederken de Türkçe yazmayı tercih etmiştir: "Ata bizüm ki kökte sen, alguşludur senün adun, kelsün senün hanlugun bolsun senün erkün alay yerde u kökte, ver bizüm ötmekimizni bugün, goy bizüm yasogni, alay biz dagi goyalum bizüm yasoglomuzni, goyma bizni sunamaga, illa gurtar bizni yamandan! Amin (Ey gökteki babamız, adın kutsansın hâkimiyetin bize uzansin, iraden gökte olduğu gibi yerde de yürüsün. Bize günlük ekmeğimizi ver ve bizi borçlularımızı bağıs̆lamamız gibi (sen de) bizim borçlarımızı (günablarımızı) bağışla ve yolumuzu şaşırtma (bilâkis) kötülüklerden kurtar! Amin)"

Görsel 1: Schiltberger'in Eserinde Türkçe Pater Noster Duası (Schiltberger 68r-69v; 96v; Türkçesi: 21-22; 165-166).

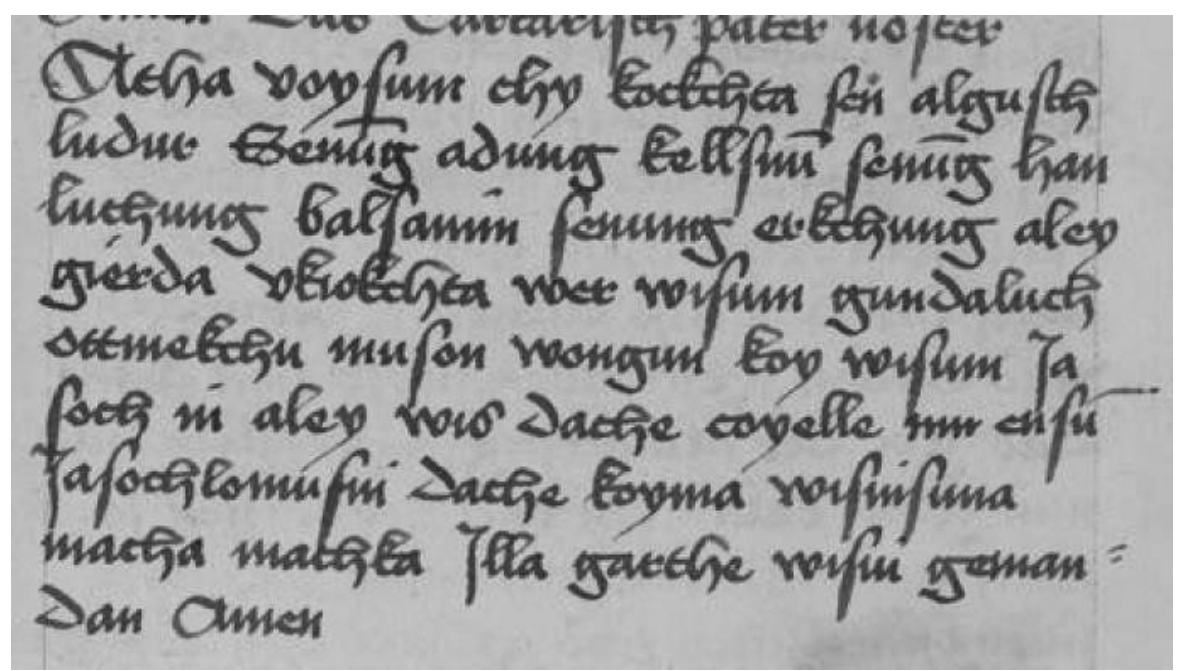

Schiltberger'in eseri hem söz konusu metinlerin ilk örneğidir hem matbaada basılmıştır. Bu özelliğiyle eser, daha sonra yayınlanacak kitaplar için bir örnek 
niteliğindedir. Zira matbaanın yaygınlaşması Avrupa'da benzer tarzda birçok eser yayınlanmasına vesile olmuştur.

\section{Matbaanın İcadı ve Latince Dışındaki Dillerin Yaygınlaşması}

Avrupalılar tarafindan Latin harfleriyle Türkçe metinler yazılmasında matbaanın doğrudan olmasa da dolaylı katkısından bahsedilebilir. Bir yabancı dili öğrenmek ve onu konuşmak şahsi bir kazanım olarak değerlendirilebilir. Ancak söz konusu dili öğrenen kişinin birikimini yazıya geçirmesi, bilginin daha kalıcı hâle gelmesine/yayılmasına vesile olur. Dolayısıyla yazma eylemi, bilginin muhafazası ve öğretilmesi amacını da taşır. Matbaa, yazılı metnin hızla çoğaltılmasını ve daha geniş kitlelere ulaşmasını sağladığı için bilginin muhafazasında ve yayılmasında daha ileri bir aşamayı temsil eder. Matbaanın icadıyla insanların öğrenme merakı daha kolay tatmin edilebilir olmuş, bu da Avrupa’da Türkçe öğrenen insan sayısının artışını beraberinde getirmiştir. Dolaylı olarak da bazı kişilerin kendi bilgilerini ve deneyimlerini yazıya geçirip yayımlamaları neticesinde Latin harfleriyle basılmış Türkçe ibareler içeren eserlerde ciddi bir artış meydana gelmiştir. Avrupa'da Türk kültürüne ve diline olan merakın arttığ 1 dönem, matbaanın icat edildiği erken modern döneme koşut gider. Nitekim yukarıda değinilen Schiltberger'in hatıratının yayınlanmas1, Johannes Gutenberg'in ilk matbaayı kurmasının (1447) hemen akabindedir.

Matbaadan önce kitaba erişim, dolayısıyla okuma imkânı ruhban sınıfina özgü bir ayrıcalıktı. Matbaa ile birlikte muhtelif dillerde kitaplar basıldığ gibi geniş kitlelerin de kitaplardan istifade etmeleri sağlanmıştır. Bu icat, kısa sürede bütün Avrupa'ya yayılmış, 1450 yılında sadece bir olan matbaa sayısı, 1500 yılında 250 merkezde 1.700 'e yükselmiştir. Matbaalarda elli yıl zarfinda 27.000 kitap basılmış, bu kitaplardan 10.000.000'dan fazla kopya üretilmiştir (Fischer 2003: 207).

Matbaacılık tarihinde önemli bir yeri olan Mainz şehri aynı zamanda Arap harfli ilk kitabın basıldığı yer olmuştur. Bernhard von Breydenbach'ın Kudüs'e yaptığı hac seyahatini anlatan seyahatnamesi 1486 yılında Mainz'de basıldığında içerisinde matbaada klişe baskı yöntemiyle basılan ilk Arap alfabesi de bulunmaktayd. 
Görsel 2: Breydenbach'in Seyahatnamesinde Yer Alan Arap Alfabesi (Breydenbach 1486: 4).

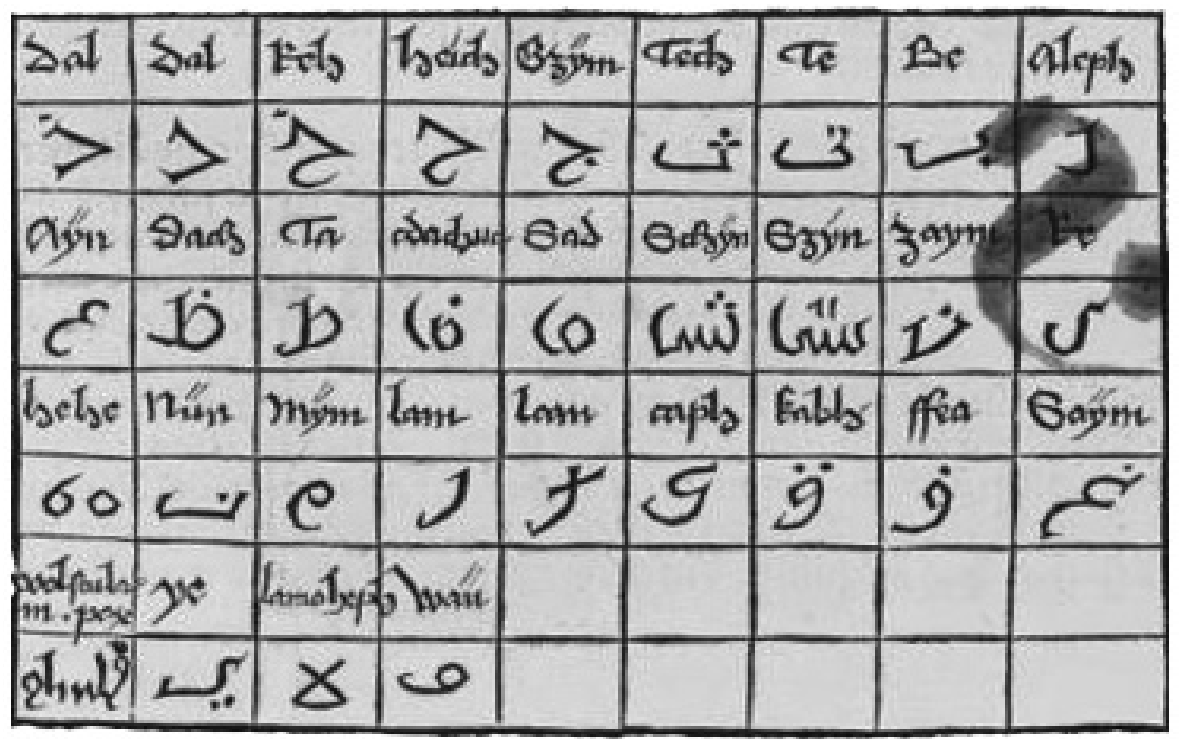

Ortaçağda Batı düşünce dünyasının yegâne dili olan Latincenin yaygın kullanımının gerileyip, ulusal dillerin etkinlik kazanmasında ve gelişmesinde matbaanın rolü büyüktür. Aragon’da 1501-1510 yılları arasında 25 Latince kitap basılırken, 15 İspanyolca kitap yayınlanmıştı. Sonraki otuz yıl içinde 115 Latince, 65 İspanyolca; 1541-1550 döneminde 14 Latince esere karşıllk toplam 72 İspanyolca eser meydana getirilecektir. Almanya'da ise matbaa, reform hareketinin etkisiyle Almancanın önem kazanıp Latince karşısında güçlenmesini sağlamıştır. Burada 1501-1525 yılları arasında Almanca 4000 eser basılmıştır. Almanya'da 1519 yılında sadece 40 Almanca eser mevcutken, bu say1 1521 'de 211 'e, 1522 'de 347 'ye 1525 'te de 198 adedi Luther'in eseri olmak üzere, toplamda 498'e ulaşmıştır (Febvre-Martin 2000: 39-40, 140141, 234-236).

Latince, XVII. yüzyılın ortalarına kadar bürokrasiden, bilim ve din işlerinin yürütülmesine kadar geniş bir alanda otoritesini muhafaza etmişse de XVI. yüzyıldan itibaren diğer diller de gelişmiştir. İncil'in Avrupa dillerine çevrilmesi bu gelişimde etkili olmuştur. Nitekim Martin Luther, İncil'i 1521 yılında Almanca, William Tydale de 1526 yılında İngilizce basmıştır. Danimarka'da ve İsveç'te İncil'in yerel dillerde okunmasına 1530'da izin verilmiştir (Manguel 2010: 89-90). Farklı Avrupa dillerinde erken modern dönemde yapılan dinî içerikli yayınlar, ibadette ve dinî eğitimde ulusal dillerin önem kazanmasına büyük etki etmiştir. 
Bu dönem Osmanlı Devleti'nde gayrimüslim reaya tarafından ilk matbaaların kurulduğu döneme tekabül etmekteydi. Türkiye'de matbaanın öncüleri David ve Samuel Nahmias adlı iki Yahudi kardeştir. Nahmias kardeşler Napoli'den getirdikleri harf takımlarıla bu matbaada ilk olarak 13 Aralık 1493'te Jacob ben Ašer' in 'Arba'ah Țûrîm adlı kitabını bastılar (Offenberg 1996: 221-235).İlk Ermeni matbaası ise bundan yaklaşık yetmiş yıl sonra Abgar Dpir Tokhatetsi tarafından 1567 yılında kuruldu. Abgar Dpir Tokhatetsi, matbaacılığ1 Venedik'te kaldığı dönemde öğrenmişti. Osmanlı topraklarındaki ilk Rum matbaası da Nikodemos Metaxas adlı Rum kökenli Venedik tebaasından bir Ortodoks rahip vasitasıla 1627'de kurulmuştur (Pektaş 2015: 16-17; Teotig (Teotoros Lapçinciyan) 2012: 72-74; Meral 2016: 27-35).

Osmanlı topraklarında Yahudi, Ermeni ve Rum matbaalarının kuruluşunda İtalyan şehir cumhuriyetlerinin doğrudan ya da dolaylı etkisi olmuştur. Matbaacılık eğitimi, alet edevatı dışında kâğıt da İtalyan şehir cumhuriyetlerinden temin edilmekteydi. Venedikli Luigi Bassano, Osmanlı topraklarında bulunduğu dönemde (1532-1540) Osmanlıların İtalya yarımadasından ithal ettikleri bambacina adlı bir kâğıt türünü kullandıklarını müşahede etmişti (Bassano 1545: 58v; Türkçesi: 162). İtalyan şehir cumhuriyetleri, tabiiyetleri altındaki insanlar veya buralarda matbaacılık faaliyetlerini öğrenen kişiler aracılığıyla değil, bizzat kendi kurdukları matbaalarla da Osmanlı'nın kültür hayatına doğrudan katkıda bulunmuşlardır. Örneğin Floransalılar 1584 yılında, Medici Matbaası olarak anılacak “Tipografia Medicea”yı kurmuşlardır. Bu matbaa, Papa XIII. Gregoire'nin çabalarıyla Kardinal Ferdinand de Medicis vasıtasıyla Vatikan tarafindan finanse edilmekteydi. Medici Matbaası Arap harfli kitaplar basmak için kurulmuştu. Matbaanın yönetimine, gençliğinde Osmanlı topraklarında bulunarak Arapça, Türkçe ve Farsça öğrenmiş olan Gianbattisra Riamondi getirilmişti. Kullanılacak Arap harflerinin üretimi görevi ise kuyumcu hakkâk Robert Granjon'a verilmişti. Medici Matbaası'nın kuruluş gayelerinden birisi Orta Doğu coğrafyasındaki Hristiyanları Vatikan’a bağlayacak yayınlar yapmaktı. Bir diğer amaç ise matbaası olmayan doğu toplumları için kitap basarak para kazanmaktı. Ayrıca Arap harfli basılacak metinlerle Avrupa bilimine katkıda bulunmak da hedefler arasındaydı (Erden 1995: 186-187; Bloom 2003: 288-289; Şakiroğlu 1995: 222).

Medici Matbaası'ndan (Tipografia Medicea) sonra 1622 y1lında Roma'da Insanları İnanca Davet Etme Cemiyeti (Congregatio de Propaganda Fide) vasıtasıyla Arapça eserler neşreden bir yayınevi kuruldu. Bunun dişında 1680'li yıllarda Padova'da Tipografia del Seminario adlı yayınevi kuruldu. 
Yayınevi 1698'de Arap harfli asli ile birlikte Latince tercümesi olan Kur'an-ı Kerim'i bast1 (Pedersen 2012: 140).

Erken modern dönem öncesinde ve bu dönemde Avrupa'da en fazla ilgi uyandıran dinî metinlerinden birisi Kur'ân-ı Kerim'di. Bunun Latinceye çevrilmesinde merakın yanı sıra, İslam aleyhine kullanılabilecek argümanlar elde etme arzusu da oldukça etkiliydi (Burman 2013). Kur'ân çevirilerini, erken modern dönemde Kur'an'ın Arap harfli basılması izledi. Paganini adlı

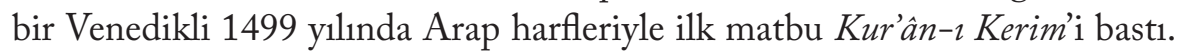
Daha sonra 1509, 1530 ve 1538 yıllarında yeni baskıları yapıldı (Şakiroğlu 1995: 220). Kur'an'dan sonra Arap harfleriyle basilan ilk eser, Kitâb-ı Salât as Sawâ' '’dir. Kitap Gregorio Gergio tarafindan kurulan bir matbaada Papa II. Julius ve Papa X. Leon'un teşvik ve yardımlarıla 1514'te basılmıştır (Erden 1995: 178-179).

Floransa Matbaasının kapanmasından sonra buradaki matbaa, Romalılar tarafindan Roma'ya taşınmış ve Doğu dillerinde kitap basma işi burada devam ettirilmiştir. Roma'da yetişen Pietro Della Vallé (1586-1652) adlı gezgin, bu matbaadaki kitaplardan ve buranın kütüphanesinden oldukça istifade etmiştir (Şakiroğlu 1995: 222-223). Della Vallé, bir seyyah olarak 1614'te geldiği İstanbul'da aldığı özel dersler vasıtasıyla Türkçesini biraz geliştirdikten sonra, bir kamus temin etmiş (Vallé 1745: I 234-235, 260-262), Arapça ve Farsça öğrenmişti. Pietro Della Vallé’den geriye Türkçe öğrenmek için tuttuğu çalı̧̧ma defteri (Vallé 2011: 13-14, 23-30) ve içerisinde Latin harfleriyle Türkçe yazılmış şiirlerin de bulunduğu bir divanı kalmıştır (Speelman 2002: 1-37).

İtalyan şehir cumhuriyeti tabiiyetine mensup şahıslar Osmanlı topraklarında farklı milletlerin kurdukları matbaalara doğrudan destek olma, kâğıt temin etme ve kendi kurdukları matbaalarda eserler basma dışında bizatihi kendileri de Latin harfli Türkçe metinler kaleme almışlardır.

\section{LATİN HARFLERIYLE TÜRKÇE YAZANLAR}

\section{İtalyan Şehir Cumhuriyetleri Tebaasına Mensup Olanlar}

Medici Matbaasında basılan eserlerle Türkçeyi öğrenmek isteyen İtalyan şehir cumhuriyeti tebaası için iyi bir birikim oluşturulmuştu (Şakiroğlu1995: 221). Medici Matbaasıyla başlayan Avrupa menşeli Arap harfli kitaplar, kısa sürede Osmanlı topraklarında satılmaya başlandı. Öyle ki bu kitapları satmak için Osmanlı topraklarına gelen Branton ve Orasyu oğlu Bandini adlı tüccarların ellerindeki kitaplara bazı şahıslarca el konulunca, durum 
padişaha akseden bir şikâyete neden oldu. Neticede III. Murad (1574-1595), İtalyan şehir cumhuriyeti tebaası tüccarlarının Osmanlı topraklarında kitap satışlarına devlet tarafından müsaade edildiğini ve hiç kimsenin bu tüccarların faaliyetlerine müdahale etmemesini emreden bir fermanıyla (Ekim-Kasım 1588) söz konusu ticareti güvence altına aldı. İtalyan şehir cumhuriyeti tüccarları da muhtemelen kendilerine tanınan bu hakka dair fermanı, istenilen her ortamda ibraz edebilmek için Öklid geometrisi hakkında Nasıreddin Tusi'nin yazdığı ve Medici Matbaasında basılan bir kitabın sonuna ilave etmişlerdi (Nasir al-Din al-Tusi 1594: 454). Matbaada basılan Latin harfli Türkçe metinler kendilerinden sonra benzer tarzda eserlerin yayınlanmasında da etkili oldu. Örneğin Bernardino Pianzola (Pianzola 1777: IV) ve Johannis Christiani Clodii (Clodii 1730: VII) eserlerini yazarken Meninski'nin sözlüğünden yararlandıklarını ifade etme ihtiyacı hissetmişlerdi.

İtalyan şehir cumhuriyetleri mensupları mevcut eserleri basmakla kalmayıp aynı zamanda kendileri de Türk kültürü ve dili hakkında ayrıntılı araştırmalar yapmışlardır. Gambatista Toderini (doğ. 1728- öl. 1799) adlı Venedikli dil bilimci, Türk edebiyatı üzerine üç ciltlik Letteratura Turchesta adlı bir eser yazmışırı. Kitabını yazarken Venedik'teki kitap basım faaliyetleri neticesinde basımı yapılan kitaplardan ve Türkçe öğrenmek/öğretmek çabalarıyla oluşan kültürden istifade etmiştir. Toderini, eserinin ilk cildinde Türklerin okudukları gramer, musiki, matematik gibi ilim dalları hakkında bilgi verirken, ikinci cildinde İstanbul'daki medrese ve kütüphanelerden, üçüncü cildinde de İbrahim Müteferrika matbaasına ve burada basılmış eserlere dair bilgiler vermiştir (Toderini 1787).

İtalyan şehir cumhuriyetleri, gerek Osmanlı topraklarındaki gayrimüslim cemaatlerinin matbaalarının tesis sürecine gerekse İtalyan şehir cumhuriyetlerinin kendi matbaalarında bastıkları Arapça, Farsça, Türkçe kitapların Osmanlı reayasına ulaşmasına katkıda bulunmuşlardır. Şüphesiz bu katkıda cumhuriyetlerinin Yakın Doğu ve Orta Doğu bölgesindeki ticari ve diplomatik ilişkileri etkili olmuştu. Nitekim İstanbul'daki en eski diplomatik temsilcilikler İtalyan şehir cumhuriyetlerine aittir. Venedik'in İstanbul'daki diplomatik temsilciliğinin kurulması Türk hâkimiyetinden önceye dayanır.

İstanbul'da 1408'den itibaren bir Venedikli, 1414'ten itibaren Polonyal, 1497'den itibaren Rus, 1525'ten itibaren Fransiz, 1528'den itibaren Avusturyalı diplomatik misyon görevlilerinin bulunduğu bilinmektedir. İstanbul'da Floransalı ilk konsolosun 1461 yılından itibaren Pera'da (Beyoğlu'nda) var olduğu da malumdur. İstanbul'da erken sayılabilecek tarihlerden itibaren 
diplomatik temsilcilik kurmalarından ötürü İtalyan şehir cumhuriyetlerinin söz konusu temsilcilik çalışanları arasında erken dönemlerden itibaren Türkçe öğrenme merakı başlamıştır. Türkçe öğrenip eser yazan misyon üyelerinin çalı̧̧maları, kendilerinden sonra Türkçe öğrenmek isteyenler için de birer kaynak vazifesi görmüştür. Giovanni Lotti'nin Floransa konsolosluğu döneminde (1524-1528) elçilik sekreterliğini yürüten Filippo Argentini, 1533'te Regola del Parlare Turcho (Türkşe Konuşma Kuralları) adlı bir kitap yazmış ve bunu İstanbul'daki ilk amiri Giovanni Lotti'nin oğlu Ridolfo Lotti'ye ithaf etmiştir. Argentini, eserinin başında Giovanni Lotti'nin konsolosluğu esnasında "dünyanın bu kössesiyle sıkı ilişkiler içerisinde olacak herkese yararlı olacağı umuduyla başladığını” ifade etmekteydi. Filippo Argentini'nin Türkçe merakı kısa sürede memleketinde yayılmıştı. Zira pek çok hemşehrisi ve arkadaşı Türkçe öğrenmek için Türkçe ile ilgili dokümanları temin edip kendilerine göndermesini istemişlerdi. Filippo Argentini, bu talepleri karşılayabilmek için eserinden suretler çıkararak onlara göndermişti. Regola del Parlare Turcho adlı eser, daha sonra benzer tarzda yazılan pek çok eser için örnek oldu. Nitekim ismi bilinmeyen biri tarafından XVI. yüzyılda derlenen bir İtalyanca-Türkçe sözlükte Argentini'nin derlediği hemen hemen tüm sözcüklere yer verilmişti. Günümüzde bu sözlük, Bibliothèque Nationale de Paris'de A.F. Turc 219 numarada bulunmaktadır (Adamović 2009: 9-12). Argentini'nin eserine olan talep, Türkçe öğrenmeye hevesli kişilerin sayısının ne kadar yükseldiği hakkında fikir vermektedir.

Filippo Argenti'den sonra Türk dili hakkında yazdığı eser nedeniyle burada zikredilmesi gereken ilk şahıs Giovan Battista Montalbano'dur (doğ. 1596 - öl. 1646). Bolognalı bir seyyah olan Montalbano'nun yolu İstanbul'a düştüğünde, Boğdan Voyvodası Gaspare Graziani’nin/Gratiani’nin tavsiyesi üzerine Osmanlı hizmetine girmiştir. Montalbano, bir süre sonra voyvodanın isyan ettiği için öldürülmesi üzerine Venedik hizmetine girmiştir. Papa XV. Gregorio tarafindan 1622 y1linda kurulan De Propaganda Fide kongregarisyonun isteği doğrultusunda 1622-1632 y1lları arasında bir tarihte yazılmış olduğu düşünülen Turcicae Linguae per Terminos Latinos Educta Syntaxis in Usum Eorum Qui in Turciam Missiones Subeunt adlı bir eser yazd. Eser gramer kuralları, Türkçe-Latince bir sözlük ve Latin harfleriyle yazılmı̧̧ bazı atasözlerinden müteşekkildir (Gallotta 1986: 235-249).

Montalbano'nun ardından Giovanni Molino (doğ.?-öl.?) adlı bir Venedikli tercümandan bahsedilmelidir. Doğum ve ölüm tarihi tespit edilemeyen bu tercüman, daha 1641 gibi erken kabul edilebilecek bir tarihte Dittionario Della Lingua Italiana, Turchesca adlı İtalyanca-Türkçe sözlük yazmıştır. 
Görsel 3: Giovanni Molino'nun Eserinde İtalyanca Kelimelerin Türkçe Karşılıkları (Molino 1641: 142).

\section{$285 \quad 0 \quad 5 \quad 286$}

Ormefino] Darai. Ofcuro]Karanlik.

Ornamento]Sc-ohret. Offeruanza, riuerenza]

Ornare,adobbare] $\mathrm{Sc}=\mathrm{oh}$ Muedeb. retetmek.Donatmak. Offeruare, riuerire] Mue.

Ornaramente ] Szinetli- debfaklamak. ghilhe, Offeruatione] Mukaiat:

Ornare]Szinnetle mek. lik.

Oraato]Szinnetlenmifc, Officello ] Ghiemikgiv

Oro]Altun.

20 Orio,animale]Aij. Ofio] Ghiemik. Io

Oria]Difs $-\mathrm{i}$. Aij. Oftaculo,impedimento]

Qrfetto, prfo picciolo ] Paciaris . Aijgik.

Ortica, herba ] Ofurghan dikieni.

Orticello] Bakgiagik .

Ortolano] Bakgiuan .

Oftaggio ] Rehin, Amz.

net.

Oftare, impedite] Paciaris etmek.

Orto, giardino] Bakgia. OAtinarfi] Inatlanmak.

20

Orzo, biada] Arpa.

Oftipatamente ] Inati-
O
Oftunato]Inatgi.

ghithe,

OGare, asdire ] Kadic of- Oftinatione] Inatlik. mak.

OAtrega]Stridia, Strigz.

Ofcurare ] Chasanlik et- Oftro, véto di mezo di 1 mek. Sc-imal.

Ofcuramentc] Charanli- Oftro, firocco] Xieicen: ghilhe. ifc-leme.

Oicuratione, ofcuritd] Oftro,garbino] Chatbi. Charanlik.

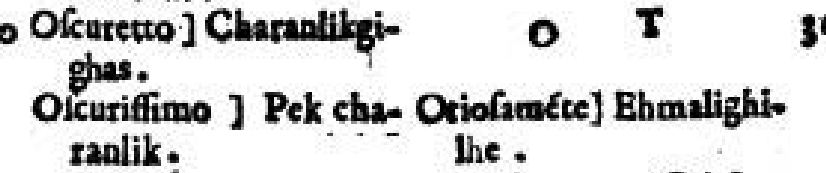

$$
\text { I } 4 \text { Otiol }
$$

Giovanni Battista Donado (1627-1699) adlı bir elçi XVII. yüzyılda Osmanlı Devleti’ne gönderildiğinde Türkçeyi öğrenmiş ve öğrendiklerini kalıcı hâle getirerek sonraki kuşaklara aktarmayı tercih etmişti. Donado, Türk dili üzerine yazdığı ve 1688 yılında basılan eserinde yer yer çeşitli atasözü, şiir vb. bazı cümlelerin Latin harfleriyle Türkçe yazımına yer vermişti. (Donado 1688: 97-100, 137139). 
Görsel 4: Giovanni Battista Donado'nun Eserinde Atasözü ve Deyimler (Donado 1688: 98)

98 Dolla Letterätura Altro.

Becleuanà aiagèn al dediler

Bolorffan gianin alerim dedi.

ciod

Fù detto al brauso, prendi li pie-

di al tuo nemico,

Et effo dice, che fe poteffe le prenderebbe anco l'animo.

Altro.

Bir tazi ichì tauflan birde totamas.

cioel

Vn Leuriero non puol prender due

Lepri in van volta.

Altro.

Ichì chedi bir arlan à pefter.

cio?

Due gatti fono Infficienti per vn

Leóne.

Altro.

Gicen dogmadan neller dogar.

Auant che nafca il giorno, mol-

te cole nafcono.

Altro.

Aref ffiad olur bù giaanc̀ nè gam

che-

Osmanlı Devleti ile İtalyan şehir cumhuriyetleri arasındaki ilişkiler geliştikçe yukarıda bahsi geçen Filippo Argenti, Giovan Battista Montalbano ve Giovanni Molino gibi iyi derecede Türkçe bilen personele sahip olmak, İtalyan şehir cumhuriyetlerinin diplomatik misyonları için hayati bir zorunluluk hâline gelmişti. $\mathrm{Bu}$ tercümanların diplomatik ilişkilerin yürütülmesi hususunda sağlayabileceği yararın anlaşılması hem tercümanların hem de 
Latin harfli Türkçe eserlerin tarihî gelişimi açısından bir dönüm noktası oldu. Venedik hükümeti İstanbul'daki elçilik işlerinin daha etkili yürütülmesi için dragoman olarak adlandırılan tercümanların yanında daha fazla personel yetiştirilmesine yönelik bir dil okulu açılmasına karar verdiler. 1551 yılına kadar Osmanlılarla siyasi münasebetlerini yetenekli vatandaşları vasıtasıyla yürütmeye çalışan Venedik, bu tarihte gençlere Türkçe öğretmek amacıyla bir merkez kurdu. Biraz Türkçe öğrenen gençler, dil eğitimlerini ilerletmeleri amacıyla İstanbul'a gönderiliyordu. Zamanla memuriyete dönüşen bu kuruma "Giovani della Lingua/Dil Oğlanı" adını verdiler.Diloğlanlarıbalyosun famiglia adlı kapı halkının bir üyesi durumundaydı. Elçilik binasında çalışmalarını sürdüren bu genç memurlar, bazı Venedik vatandaşları ile beraber zaman zaman elçiliğe çağrılan kişilerden dersler alarak dillerini geliştiriyorlardı. Bu şekilde yetişen gençler ileride Venedik-Osmanlı ilişkilerinin yürütülmesinde etkili birer aktör olacaklardı (Dursteler 2012: 4861). Okulun ilk öğrencileri Sebastiano del Cortivo ve Ludovico Marucini adlı iki çocuktu. İlk dönemde bunlar için beş senelik bir eğitim öğretim uygun görülmüştü. Başlarda iki olan öğrenci sayısı 1625-1626 arasında iki katına, eğitim süreleri de yedi yıla çıkarıldı. Bazı öğrenciler sadece Türkçeyi öğrenmekle kalmıyor, bir Türk gibi yaşamaya başlıyorlardı. Örneğin, Colombina adlı öğrenci Türk usulü bir yaşamı tercih etmiş, adını Mehmed olarak değiştirmiş hatta âş̧ı olduğu kız ile evlenebilmek için Müslüman olmuştu. Çocuklarının din değiştirmelerinden ürken Venedikli aileler oğullarını İstanbul'a göndermekte isteksiz davranmaya başladılar. Bazı dil oğlanları da, ya İstanbul'un havasına alışamadıkları için ya da muhtelif hastalıklar nedeniyle eğitimlerini yarıda bırakarak memleketlerine dönmek zorunda kaldı. Tüm bu nedenlerden Venedik’ten İstanbul'a gelen dil oğlanı sayısı zamanla gittikçe azaldı. Bir müddet sonra da bu okul daha ziyade Katolik Osmanlı reayasının oğullarına iyi bir gelecek sağlamanın aracı hâline geldi. Söz konusu okula kabul edilmek, babadan oğula geçebilen kazançlı bir gelire sahip olmak demekti (Pedani 2015: 173-174).

Sözü edilen okuldan yetişen dil oğlanları dışında diplomatik ya da dinî görevler nedeniyle Osmanlı topraklarında bulunan pek çok İtalyan şehir cumhuriyeti mensubu, Türkçe öğrenmiş ve öğrendiklerini Latin harfleriyle yazıya geçirmiştir. Örneğin, Kıbrıs doğumlu bir Venedik vatandaşı olan mütercim Michele Membré (1509-1594), Türkçeyi, Arapçayı ve Farsçayı ileri derecede öğrenmişti. Membré, ülkesinden 1539'da aldığı bir emirle önce deniz yoluyla Urla'ya gelmiş, buradan kara yoluyla Ankara'ya, oradan Samsun'a gitmişti. Membré daha sonra deniz yoluyla Gürcistan üzerinden 
Safevî ülkesine ulaştı. Burada Şah Tahmasb nezdinde ülkesi adına bir dizi görüşme yaptıktan sonra, Lizbon'a gitti. Burada seyahati hakkında bir sefaretname yazarak Venedik'e döndü. Türk tüccarların sorunlarıly ilgilendi ve devleti adına birçok Osmanlı Türkçesi belgenin çevirisini yaptı. Membré, 1544'te kısa bir müddet için İstanbul'da bulundu. Resmî olarak balyoslukta tercümanlık yapmamış olmakla birlikte İstanbul'da bulunduğu süre zarfinda bazı notlar almıştır(Şakiroğlu 1992: V, 46). Her ne kadar resmen Venedik balyosluğunda tercümanlık yapmamış olsa da ülkesi adına tercümanlık faaliyeti yürüttüğü için Michele Membré, bir tercüman olarak kabul edilebilir. Bugün Michele Membré ile Osmanlı mütercimi İbrahim adlı bir şahsın 1567'de Latin harfleriyle Türkçe mektuplaştıklarından haberdarız (Şakiroğlu 1992: 278-279). Michele Membré, yalnız bir tercüman değildi. Osmanlı padişahının büyüklüğünün reayası tarafından da anlaşılabilmesi adına bir Venedik atölyesine yapımı sipariş edilen üzeri açıklamalarla çevrilmiş bir haritanın yapımında görevliydi. Anlaşıldığı kadarıyla devrinde VenedikOsmanlı ilişkilerinde yalnızca siyaset değil ticaret gibi çok daha geniş alanlarında da etkili bir isimdi (Casale 2014: 96-119).

İtalyan şehir cumhuriyetlerinden birine mensup bir diğer şahıs, Osmanlı askerî durumu hakkında bilgi edinmek için Osmanlı topraklarına gönderilen Bologna doğumlu Venedikli askerî ataşe Luigi Fernando Comte de Marsigli (doğ. 1658 - öl. 1730) idi. Marsigli, Osmanlı askerî tarihi açısından olduğu kadar sosyal tarihi açısından da kıymetli eserinde sık sık bazı eşya isimlerinin Latin harfleriyle Türkçe yazılışlarına yer vermiştir (Marsigli I 1732).

Latin harfleriyle Türkçe eser kaleme alan bir başka İtalyan şehir cumhuriyeti tebaası Ermeni asıllı Cosimo Comidas de Carbognano (1749-1807'den sonra)'dur. Sicilya elçiliğinde tercüman olarak çalışmış Hovhannes Kömürciyan'ın (1700-1764) oğlu olup asıl adı Kozmas Komidas Kömürciyan'dı. Öğrenimini İtalya'da tamamladıktan sonra Napoli elçisi Kont Ludolf'un tavsiyesi üzerine 10 Ekim 1778'de Napoli elçiliğine dil oğlanı olarak atanmı̧̧ı. Bir müddet bu görevde çalıştıktan sonra 1785 'te İspanya elçiliğine tercüman atanmı̧ ve ölümüne kadar bu görevi sürdürmüştü (Pamukciyan 2003: 281282). XVIII. yüzyıla ait İstanbul coğrafyası kitabından başka (Carbognano 1993), Türkçe grameri hakkında Primi Principi Della Grammatica Turca, Ad Uso Dei Missionari Apostilici di Constantinopoli adlı bir kitap yazmıştır. 
Görsel 5: Cosimo Comidas Carbognano'nun Eserinden Bir Sayfa (Carbognano 1794: 4):

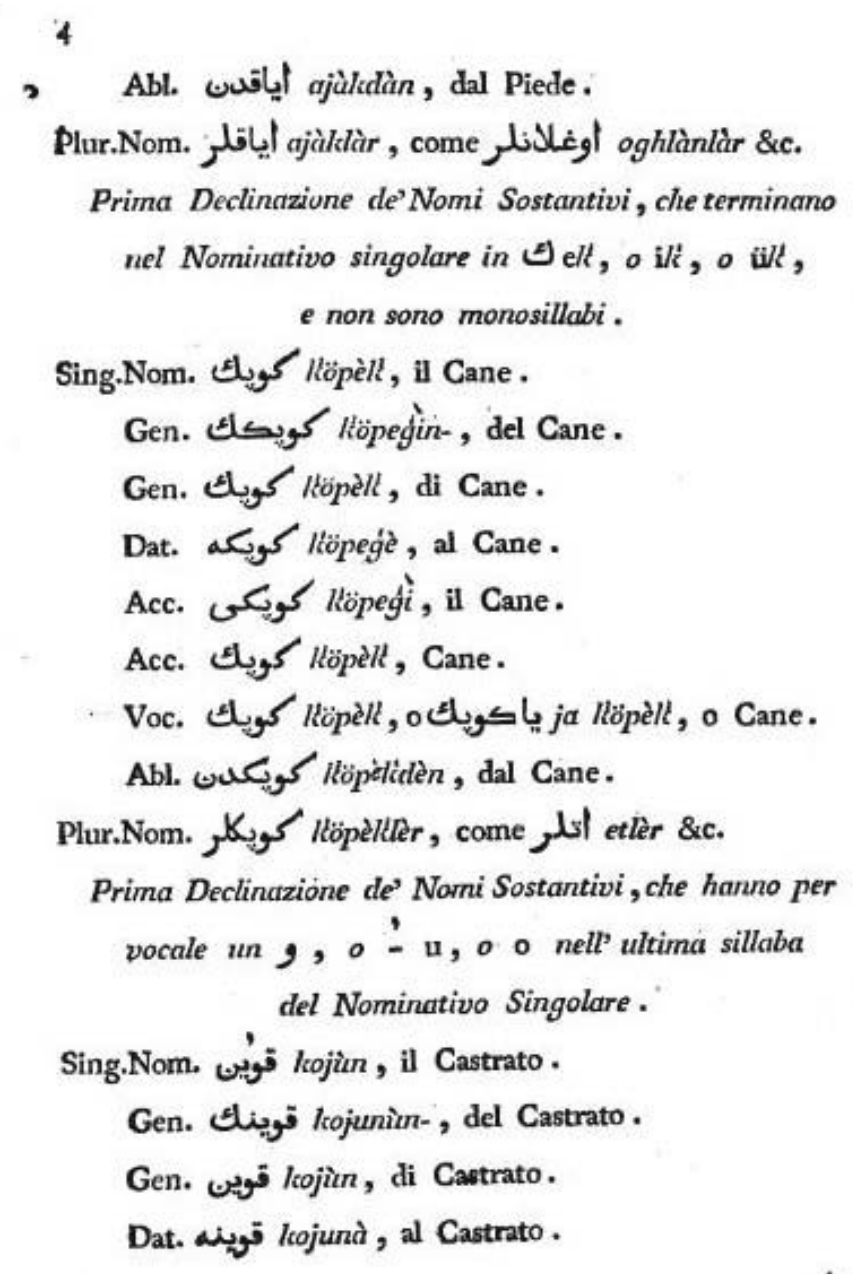

Acc.

İtalyan şehir cumhuriyetlerinin diplomatik misyon üyeleri dışında din adamı kimliğine sahip tebaasından birçok şahıs da dinî idealleri için bir araç olarak gördükleri Türkçeyi öğrenmişler ve Latin harfleriyle Türkçe ibareler içeren metinler yazmışlardır. Bunlardan birisi, peder-misyoner sıfatıyla geldiği Osmanlı topraklarında Hristiyanlığı yaymak amacıyla Türkçeyi bir araç olarak kullanan Bernardino Pianzola'dır. Yazılarında bazen Türkçe diyaloglara/kısa cümlelere (Pianzola IV 1789: 42) yer verirken, bazen de eserinin tamamina yakınını Türkçe yazmıştır. Mesela 1777'de basılan Kyssa Christoneaghan Vartabedutiunun Muktaseri Stambolda ve Edrinede Surp Andonun Kilisesinde P. Bernardinos Pianzola Öjrettijine Göre adlı eserin ana metnini oluşturan 
84 sayfanın 83'ü Latin harfleriyle yazılmış Türkçe'den ibarettir. Pianzola, bu eserinde Araplara, Ermenilere, Marunilere ve Müslümanlara Türkçe hitap etmekte, tüm muhataplarını Hristiyanlı̆̆a davet etmekteydi (Pianzola 1777: 1).

Görsel 6: Bernardino Pianzola'nın Eserinin Giriş Kısmı (Pianzola 1777: 1).

XYSSA CHRISTOQNEAGAN VAR TABEDUTIVNUN MUKT TSERI.

\section{Anwm Hor, jev Virtue, jov Bokion Surpo. Amin.}

Sual. GEni k'im jaratty., ve duojaje S kadu ?

Geveb. Allah Effendimiz.

'S. Nic̈in feni jaratty, ve danjaje kodu?

C. Opur-anymak icin, fevmek ičin, ve ona chyzmet etmek ic̄in bu öanrü̉e, ve örede bir ebedie Genaette onun dövletini fürmek ičin.

S. Allahy tanymak İcin; fevmek ičin, ve ona chyzmet etmek icin bu dunjade, ve ötede bir ebedie Gennette onan dövletini fürmek ičin, ne la. zymdyr ?

G, Eji Chtiltion gi gibi giečinmek, ve ölmek lazymdyr.

S. Sen Chriftianmisin?

G. Chriftianym, ve dachy Katolikym, súkiür Allaha.

S. Cbriftian demek ne demektyr?

G. Jfus Chriftofun Sabyrty, ve vaftizde Chryzmeilan, jani Trosmulen otzial

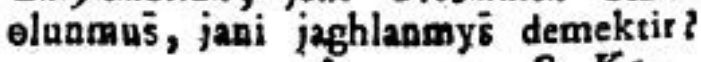

S. Ko-

İtalyan şehir devletleri tebaasından zikredeceğimiz son isim Mihitarist bir Ermeni keşişi olan P. Samuel Catergian'dır. Catergian'ın eseri, XIX. yüzyılda büyük ölçüde Batı medeniyet dairesine girmeye çalışan Osmanlı Devleti’nde devrin evrensel dili kabul edilen Fransızcayı öğrenmek isteyen öğrencilere ve ilgili kişilere bir el kitabı olması için yazılmış karşılıklı konuşma kılavuzu (Türkçe-Fransızca-Almanca konuşma el kitabı)'dur. 
Görsel 7: P. Samuel Catergian'in Eserinden Bir Sayfa (Catergian 1855: 4)

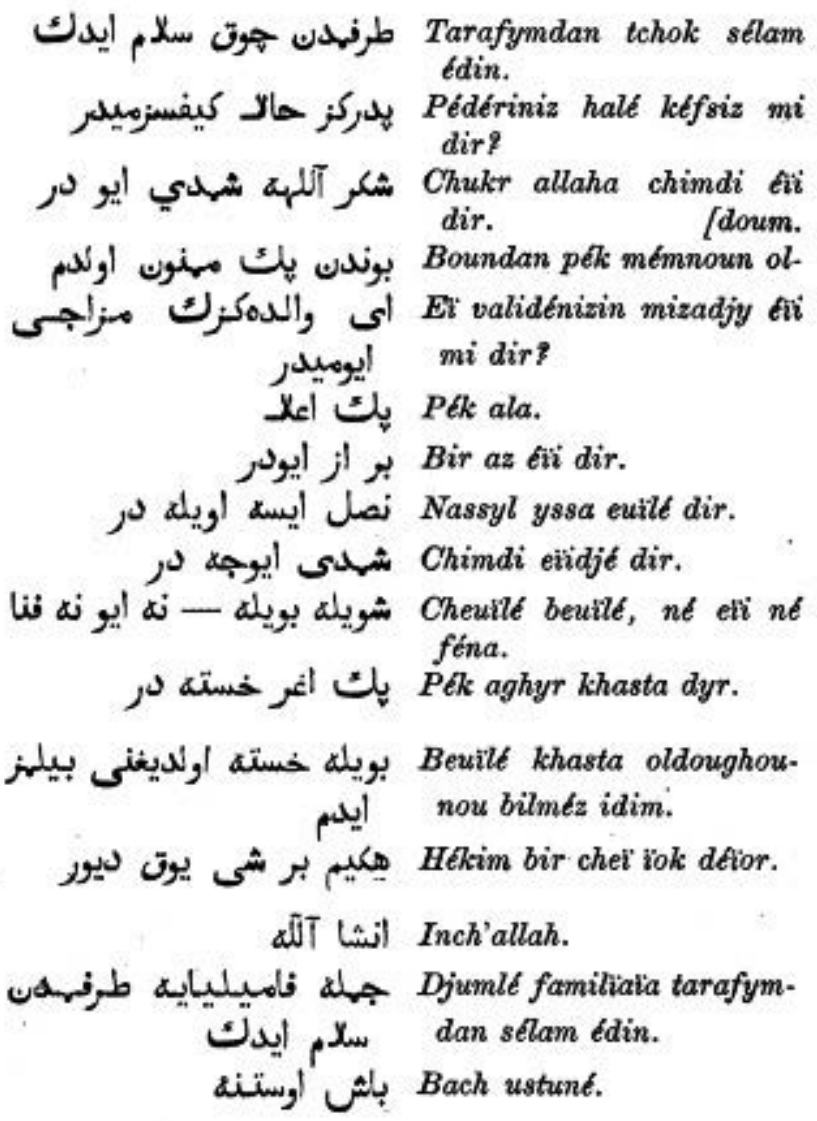

Fransizlar ve Almanlar

Avrupa'da İtalyanlardan sonra en fazla Latin harfli Türkçe metin vermiş olanlar Fransızlardır. Kanuni Sultan Süleyman'ın I. François zamanında Fransa'ya yardım etmesi ile başlayan iki ülke arasındaki yakınlaşma, sonraları askerî işbirliğine dönüşmüştür. Nitekim 1543-1544 y1llarında Kutsal RomaGermen İmparatoru V. Karl'ın Akdeniz'deki ve Avrupa'daki etkinliğini sınırlamak amacıyla Osmanlı Devleti ile Fransa'nın ortaklaşa icra ettikleri tatbikatın (Verhaaren 2015) ardından iki ülke arasında uzun süre devam edecek bir dostluk tesis edilmiştir. İlişkilerin artması Fransızların Türkçeye duydukları ilginin de artmasına neden olmuştur.

Fransa'nın İstanbul'daki ilk elçiliği de Kanuni Sultan Süleyman zamanında açılmıştır. Elçi Jean de la Forest ile birlikte 1535 y1lında İstanbul'a gönderilen Guillaume Postel (1510-1581), I. François devrinde 1530 yılında aç1lan 
Collège de France'da Arapça, Yunanca, İbranice eğitmenliği yapmış, Fransa'da Doğu araştırmalarının öncüsü olmuş bir kişiydi. Batı dilleri dışında İbranice, Keldanice, Süryanice, Grekçe ve Arapçayı öğrendikten sonra Doğu ülkelerinden el yazması eserler toplamakla görevlendirilmişti. Paris'e döndüğünde beraberinde matematik, tıp, felsefe, kozmografya ve din sahalarında yazılmış pek çok kitap getirmişti (Arıkan 1984: 68-82; Nicolay 2014: 59-60). İstanbul'da kaldığ1 dönemde bildiği dillere Türkçeyi de eklemiş ve 1575 yılında basılan eseriyle Latin harfleri ile Türkçe yazan ilk kişilerden olmuştur (Postel 1575).

Guillaume Postel'den sonra anılması gereken André Du Ryer (1558-1660)'dir. Ryer Fransa elçisinin tercümanı olarak görev yapmış ve 1630 yılında basılan Rudimenta Grammatices Linguae Turcicae adlı eserinde Latin harfleriyle Türkçe yazmanın örneklerini vermiştir.

Görsel 8: André Du Ryer'in Eserinde Bazı Kelimelerin Latin-Arap Harfli Türkçe Yazılışları (Ryer 1634: 94):

\section{4}

fecundus, ex 2 guatwor, fit ordina-

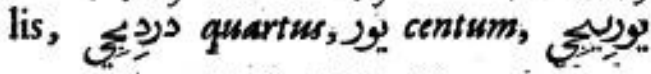
centefimus. Et fiedefimilibus.

EXERCIT ATIO LECTIONIS Lingue Turcice.

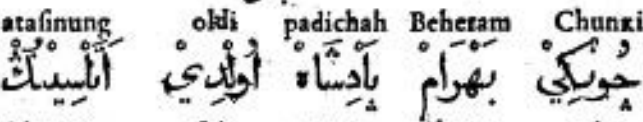

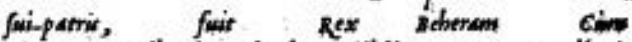
Nouman milxni Arab Gildimoucarraramellerini

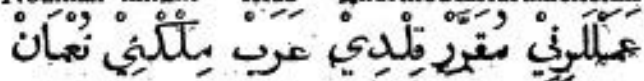
Nowman regnem Craboum, cayirmawit fatts dinenden Arab Noums bou Kildi moucarrar eleddch

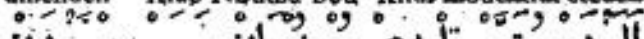

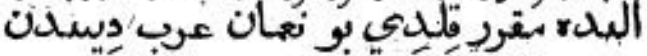

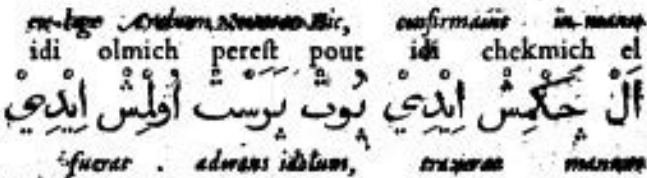
Beheramung bin Beheram melix ta zamanéden Chabour

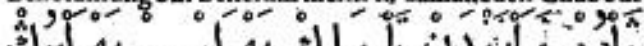

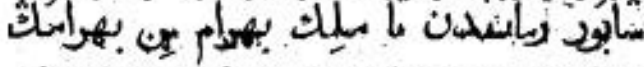

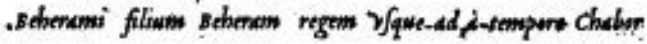


Fransa'nın Osmanlı topraklarına gönderdiği elçilik heyetlerine katılarak Türkçe öğrenen bir diğer seyyah, 1639 yılında geldiği Osmanlı topraklarında iki yıla yakın kalmış olan Clausier de Loir'dir. Türkiye'ye dair gözlemlerini 1654 yılında basılan seyahatnamesinde toplayan Loir, eserinde özellikle dua, ilahi vb. dinî metinleri Türkçe yazmaya önem vermiştir (Loir 2016: 107128)

Aynen İtalyan şehir cumhuriyetlerinde olduğu gibi İstanbul'daki elçilikte ihtiyaç duyulan tercümanları yetiştirmek, diplomatik ve ticari ilişkileri daha iyi idare edebilmek amaciyla 1551 y1lında Venedik tarafindan kurulan dil oğlanları okulunun bir benzeri Enfants de langue adıyla 18 Kasım 1669 tarihinde Fransa'da kurulmuştur. Kral XIV. Louis'in nazırı Jean Baptiste Colbert'in teşviki ve Marsilya ticaret odasının isteği ile açılan bu okul, daha sonra Jenues de Langue adını alacak (Hitzel 1995: 19) ve Fransa'nın ihtiyaç duyduğu tercüman kadrolarının önemli bir kısmı buradan karşılanacaktır. Dil oğlanları okulunda eğitim alması için 1807'de İstanbul'a gönderilen Thomas Xavier Bianchi (1783-1864), sağllk sorunları nedeniyle 1815'te Fransa’ya dönmek zorunda kalınca Doğu dilleri yardımcı tercümanlığına atanmıs, burada Türkçe-Fransızca ve Fransızca-Türkçe konuşma kılavuzları hazırlamaya girişmiştir. Dictionnaire Français-Turc adlı eserini 1843'te tamamlamıştır (Bianchi 1843; Hitzel 1995: 115).

Dil oğlanları dı̧̧ında Fransa tebaasına mensup olup tercümanlık yapan ya da dil oğlanlarının eğitiminde rol oynayan rahip, seyyah, mimar, ressam, dil bilimci gibi vasıflara sahip bazı şahıslar da Latin harfleriyle Türkçe yazmışlardır. Bu şahıslardan birisi, XIV. Louis'nin yaklaşık kırk yıl Türkçe ve Arapça tercümanlığını yapmış olan François Pétis de La Croix (16221695)'tir. Bunun Türkçe konusundaki becerisi gündelik çevirinin çok ötesindeydi. Dictionnaire Manuscrit Français et Turc, Etat general de l' Empire Ottoman, Dictionnaire Turc-Français et Français-Turc gibi eserler kaleme alması dışında, 1655-1656 yıllarında Osmanlı topraklarında bulunan Jean Thèvenot'un seyahatnamesinin başına yazdığı manzum takriz, onun Türkçeye ne kadar hâkim olduğunun göstergesidir (Duru vd. 2010: 223-229).

Bir elçilik çalışanı olmamakla birlikte, burada bahsedilmesi gerekenlerden birisi de Jean Baptiste D. Holderman (1694-1730)'dir. Holderman Galata semtinde Saint Benoît misyonunda görevli bir Cizvit rahibiydi. Fransız elçiliğindeki dil oğlanlarının isteği üzerine Türkçe gramer kurallarına dair bir kitap hazırlamıştır. Fransa’nın o dönemde Doğu alfabeleriyle kitap basabilecek bir matbaası olmadığı için eser Holderman'ın gözetiminde bir Fransız elçiliği tercümanı vasıtasıyla 1726-1730 arasında basılmıştır (Holderman 1730; Hitzel 1995: 110). 
Aynen Jean Baptiste D. Holderman gibi din adamı hüviyetine sahip olup burada bahsi gereken bir diğer şahıs Pierre François Viguier (1745-1821)'dur. Besançon'da dünyaya gelen Vigiier, ilk eğitimini bir papaz okulunda almış ve daha sonra peder olmuştur. Katolik kilisesi tarafından Cizvitlerin Yakın Doğudaki kurumları Lazaristlere verildiğinden Galata'daki Saint Benoît'in başrahipliğine tayin edilmiştir. Bu görev nedeniyle 1783'te geldiği İstanbul'da Türkçe-Fransizca olarak kaleme aldığı ve 1790 'da Choiseul-Gouffier matbaasında basılan eserinde, Türkçe kelimelerin çekimlerini vs. tanıttıktan sonra bazı cümlelerin yazılışlarına yer vermiştir (Hitzel 1995: 111).

Görsel 9: Pierre François Viguier'in Eserinden Bir Sayfa (Viguier 1790: 160).

\section{$\mathrm{Ne}$ faqrindèn chikiayèt dylè; nè zènguinliyini hikiayèt tylè. Ne formę pas des plaintes fur votre pauvrete; $\delta$ ne faites pas thifoire de vos richeffes. \\ $\mathrm{Nè} \mathrm{sc̀ndèn} \mathrm{kimsè} \mathrm{indjinfin;} \mathrm{vè} \mathrm{nè} \mathrm{sèn} \mathrm{kimsèdèn} \mathrm{indjia.} \mathrm{Que} \mathrm{perfonne} \mathrm{ne} \mathrm{s'offenfe} \mathrm{de}$ vous; \& ne vous offenfer de perfonne. \\ Nè, sèvèrlèrsè, sèvin ; vè nè, yèrèrlèrsè, yèrin. Ne foyeq pas charmé, lorfque ton vous chérit; \& ne vous affliget pas, lorfque ton vous affige.}

Latin harfli Türkçe metin yazan bir diğer Fransa tebaası Antoine-Ignace Melling (1763-1831), pek çok etnik kökenden ataya sahip olup seyyah, mimar, ressam gibi birçok vasfa sahip bir entelektüeldi. III. Selim'in kardeşi Hatice Sultan, Baron Hübsch'ün Büyükdere'deki Batı tarzında tasarlanmış bahçesini gördügünde kendisi de benzer bir bahçeye sahip olma arzusunda olduğunu belirtince, Hübsch ona Antoine-Ignace Melling'i önerir. Hatice Sultan'in Batı tarzında tanzim edilmiş bir bahçeye sahip olma arzusu, Melling ile sık sık görüşmelerini zorunlu hâle getirir. Melling, Hatice Sultan'ın isteğini kabul etmekle birlikte Osmanlı Türkçesini konuşmayı ve yazmayı bilmediği için kendisine Fransa dil oğlanları okulundan bir tercüman verilir. Bu şekilde Osmanlı Türkçesini hem okuma hem de yazma seviyesinde öğrenen Melling, Hatice Sultan'a Latince yazmayı öğretir (Hitzel 1995: 76-77). AntoineIgnace Melling'in Latin harfleriyle Hatice Sultan'a yazdığ 1 mektuplar (Perot vd. 2001) ve gravürlerle İstanbul'u tasvir eden bir eser (Melling 1819) günümüze kadar ulaşmıştır.

Fransız tebaasından Latin harfleriyle Türkçe ifadeler bulunan eser yazan bir başka şahıs da Nassif Mallouf'tur. Gerçek adı Nâsîfibn İlyâs Mun 'im al-Ma'lûf olan Lübnan doğumlu bu dil bilimci, Arapça dışında İngilizce, Fransızca, İtalyanca ve Türkçe de öğrenmişti. İngiltere konsolosluğu baş tercümanı ve İzmir Fransız Lisesi Türkçe öğretmenliği görevinde bulunmuştu. Bir 
oryantalist olarak hayatı boyunca Latin harfleriyle yazılmış Türkçe ibareler içeren pek çok eser yazan Mallouf, özellikle Türkçe ile ilgili eserler kaleme almıştır (Mallouf 1862: I).

Latin harfli Türkçe eser veren Almanlara gelince, bunlar içerisinde zikredilmesi gereken isimlerin başında Reinhold Lubenau (1566-1631) gelir. Lubenau, Kutsal Roma-Germen İmparatorunun Osmanlı Devleti'ne 1587'de yolladığ1 elçilik heyetinde eczacı sıfatıyla bulunmuş bir seyyahtır. Yukarıda bahsi geçen Floransa elçilik sekreteri Filippo Argenti'nin İstanbul'da elden ele dolaşan eserini temin eden Lubenau, seyahatnamesine eklediği 600 maddelik kısa bir sözlüğü oluştururken bu eserden oldukça istifade etmişti (Adamović 2009: 9-12). Reinhold Lubenau, İstanbul'da bulunduğu sürede Arapların, Türklerin ve Yahudilerin dükkânlarına giderek buradaki malların isimlerini bir deftere kaydetmişti. Yalnız konuşmayı değil, okuma yazmayı da öğrenmek istiyordu. Bu nedenle seyahatnamesine gün isimlerini, ülke ve şehir adlarını; mekân ve insan isimlerini, bazı organların/uzuvların isimlerini, erkek kadın giysilerinin isimlerini, renklerin adlarını, hamam ve ahır terimlerini, ev, mutfak ve meyhane eşyalarının isimlerini, yemek /yiyecek maddesi adlarını ve günlük lisandaki bazı diyalogları eklemişti. Türkçe öğrenmek için yazarını belirtmediği bir kitaptan (Argenti'nin eserinden) istifade etmişti. Fakat Lubenau, bütün çabasına ve emeğine rağmen, Türkçe öğrenmenin çok zor olduğuna kanaat getirerek bu işten vazgeçmiştir (Lubenau 2012: 235, 454464).

Reinhold Lubenau'dan sonra kronolojik olarak dört Alman'dan bahsedilmesi gerekir. Bunlardan birincisi tarihçi, dil bilimci sıfatlarına sahip Hieronymus Megiser (1553/1554-1616)'dir. Stuttgart şehrinde doğmuş, Linz şehrinde ölmüştür. Tübingen Üniversitesi'nde eğitim almış, daha sonra da Leipzig Üniversitesinde profesör olarak çalışmıştır. Megiser, 1612 yılında basılan eserinde 220 atasözüne yer vermiştir (Megiser 1612; Dilaçar 1970: 200210). Diğeri Habsburg elçisi Giovanni Battista Podestà (1624-1703)'dır. Habsburg elçisi ve casusu olarak pek çok Doğu dilini öğrenmişti. Kitabının bazı bölümlerinde kendine yazılmış Arap harfli mektuplara aynen, Türkçe ifadelerin Latin harfli yazılışlarına da yer vermiştir (Podestà I 1692: 197). Almanlardan üçüncüsü Johannis Christiani Clodii (1676-1745) hakkında çok fazla bilgiye ulaşılamamıştır. Titiz bir çabanın ürünü olduğu anlaşılan eseri incelendiğinde Clodii'nin bir dil bilimci olabileceği akla gelmektedir. Clodii iki ciltlik ayrıntılı eserinde bazı kelimelerin, atasözlerinin, deyimlerin ve bazı diyalogların telaffuzlarının Latin harfleriyle yazımına yer vermiştir. Eser 1730 yılında Leipzig'de yayınlanmıştır (Clodii 1730). Konumuz açısından eserinden bahsi gereken son Alman bilim adamı Heinrich Julius Klaproth 
(1783-1835) ise 1820 tarihli kitabında bazı kelimelerin farklı dillerdeki karşılıklarını verirken Türkçe karşılıklarını Latin harfleriyle yazmayı tercih etmiştir (Klaproth 1820: 3).

\section{Macarlar ve Lehler}

Latin harfleriyle Türkçe metin yazarları arasında zikredilmesi gereken bir diğer millet Macarlardır. Oldukça erken bir dönemde başlayan Osmanl1Macar ilişkileri çerçevesinde Macarlardan Türkçe öğrenen ve öğrendikleri bu dili diğer insanlara öğretmek için Latin harfli Türkçe eserler yazan kişiler çıkmıştır. Bunlardan birisi 1526'daki Mohaç muharebesinde Türklere esri düşmüş olan Bartholemaeus Georgieuiz (Georgiević) (1505-1566)'tir. Georgieuiz, esaret yıllarında öğrendiği Türkçeyi başkalarına da öğretmek için yazdığı De re Turcarvm Moribus Epitome adlı kitabında gündelik hayatta kullanılan karşılıklı konuşma cümlelerinin Latin harfleriyle yazılışlarına da yer vermiştir.

Görsel 10: Bartholemaeus Georgieuiz'in Eserinden Bir Diyalog (Georgieuiz 1558: 69)

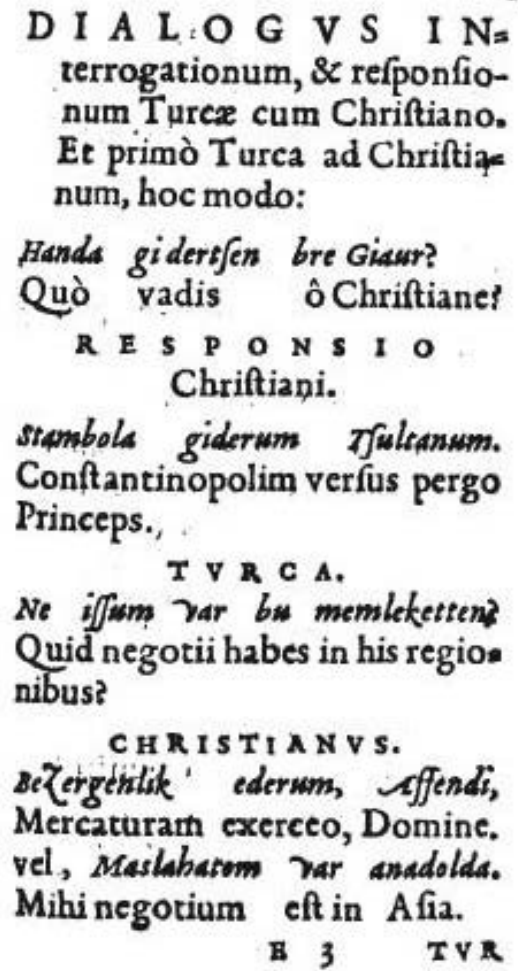


Macarlar, ilk dönemlerinden itibaren Osmanlılarla mücadele etmişler, onlarla ilişki içinde olmuşlardır. Dolayısıyla Türkçe öğrenmişlerdi. 1615 doğumlu Jakab Harsányi-Nagy, Erdel Kralı Miháaly Apafi'nin mürebbiliğini yapmış, György Rákóczi'nin emri üzerine Doğu dilleriyle özellikle de Türkçe ile ilgilenmeye başlamıştır. Erdel Krallığı maslahatgüzarı olarak yedi yıl Osmanlı topraklarında kalan (Hazai 1971: 4950), buradan taşındıktan sonra 1672'de Colloquia Familiaria Turcico-Latina: Seu Status Turcicus Loquens ad1 bir Türkçe karşılıklı konuşma kitabı yazmıştır.

Görsel 11: Jakab Harsányi-Nagy'nin Kitabından Bir Diyalog (Harsany: 1672: 2):

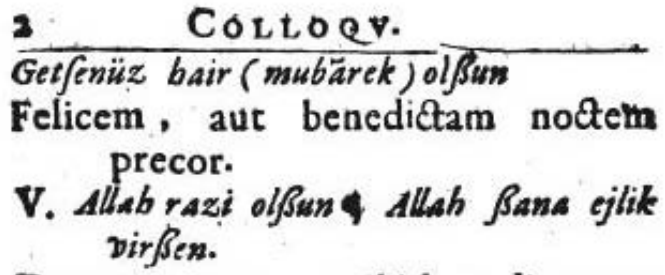

Deus acceptet, aut tibi benedicat, aut Tc fofpitet, vel : Ago tibi gratias. Hos gieldün, ßrefa gièldün.

Benè vinifti, feu Gratus eft tuus adventus.

Ejimißjin bos mifsın? Num benè valeas? vel

Nedür balin? Quomodo tecum agitur? Seuad verbúm: Quis, velqualis tuus eft ftatus?

J. Sükar Tangrie, ebos, Laus Deo, beric̀ valeo.

Hazettüm ßag gieldügünüzden,

Gratum mihi eft quòd incolumis advencris

Dizari ferifinüx makbul gecfer

Pulcherrimus vefter confpectus, ad. modum mihigratus eft.

Otura, vel, Oturun, del Oturunüz

Sede confideas, vel Sedete.

Lehler de Macarlar gibi Osmanlı Devleti ile erken dönemlerden itibaren siyasi ilişkiler kurduklarından, içlerinden Türkçe öğrenmeye ve öğrendiklerini yazılı eserler hâline getirmeye çalışan filologlar yetişmiştir. Leh asıllı dil 
bilimci Francisci Mesgnien Meninski'nin (1623-1698) Habsburg elçisi olduğu dönemde yazıp 1680'de yayınlanan devasa sözlüğü (Meninski 1680) bugün de alanında önemli bir eserler arasında sayılmaktadır.

Meninski gibi Leh as1llı olan Albertus Bobovius/Santuri Ali Ufki Bey (1610-1675) Topkapı Sarayında uzun yıllar tercümanlık yaptıktan sonra, Lehçe, Fransızca, İngilizce, Almanca, Latince, eski ve modern Yunanca, İtalyanca, Türkçe, Farsça, Arapça öğrenmişti. Musikişinas ve bestekâr kimliği ile de tanınmaktaydı. 1645 'te yapılan savaşta esir düşünce Enderun'a alınan Bobovius ihtida ederek Ali ismini almıştır. 1650'lerde Türk musikisinin bazı parçaları ile halk ezgilerinden oluşan Avrupa usulü notalarıly şiirlere ve şarkılara yer verdiği bir eser hazırlamıştır (Bobovius 2002: 12-13). Şiir ve Şarkı Mecmuası adıyla bilinen eserde bazı yapıtların notaları, Arap harfli ve Latin harfli Türkçe yazılışlarıyla birlikte verilmiştir.

Görsel 12: Albertus Bobovius'un Eserinden Bir Sayfa (Boboivus Tarihsiz: $12 \mathrm{v})$ :

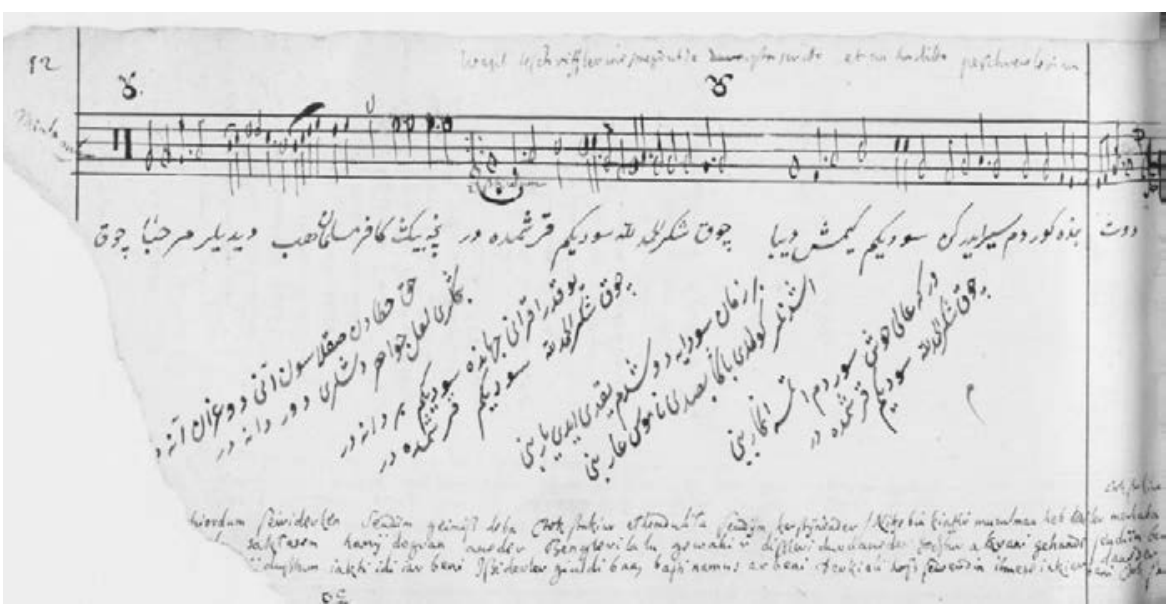

\section{İngilizler}

Latin harfleriyle Türkçe yazan topluluklardan sonuncusu İngilizlerdir. Bunların Türkçeye yönelmesinde, İngiltere'nin Osmanlı topraklarındaki ticari faaliyetleri ve siyasi emelleri etkili olmuştur. Edward Osborne, Richard Straper ve William Harborne adlı tüccarlar kendi imkânlarıyla Hamburg, Lehistan, Eflak ve Boğdan üzerinden İstanbul'a gelmişlerdi. Burada kendilerini İngiltere Kraliçesi Elizabeth'in gönderdiği intibaını uyandırmışlardı. İstanbul yönetimi, artan İspanya tehdidi karşısında İngiltere'nin bir denge aracı olarak kullanılabileceği düşüncesindeydi. William Harborne, gayretleri sonucunda 
III. Murad'dan İngiltere Kraliçesi Elizabeth adına alınmıs 15 Mart 1579 tarihli bir name-i hümâyûnla geri dönmeyi başarmıştı. Bu belge 1580 Temmuz'unda Osmanlı Devleti’nde yaşayan İngilizler için bir kapitülasyona dönüştü. İngilizler bununla da yetinmeyip Osmanlı Devleti ile İngiltere arasında ticaret yapma hususunda bir nevi tekel hakkında sahip bir şirket için izin istiyorlardı. Bu isteklerini nihayet 11 Eylül 1581 tarihinde elde ettiler. Böylece Chief Merchant of all Turkey Company (Türiye Şirketi) adlı bir şirket kuruldu. Bu şirket daha sonra Venedik Kumpanyası ile birleşince Levant Kumpanyası adını aldı. Bu anlaşmadan rahatsızlık duyan Fransız Elçisi Jacques de Germigny ile Venedik Balyosu Morosini söz konusu tekel hakkının ve İngiltere'ye sağlanan ticaret serbestliğinin iptali için yoğun çaba harcadılarsa da başarılı olamadılar (Wood 2013: 8-10, 25-35).

$\mathrm{Bu}$ şekilde Edward Osborne, Richard Straper ve William Harborne gibi üç kafadarın gayretleriyle başlayan Osmanlı-İngiliz ilişkileri giderek güçlendi. Gelişen iyi ilişkiler neticesinde pek çok İngiliz farklı nedenlerle Osmanlı topraklarına gelerek Türkçe öğrenmeye başladı. Bunlardan William Seaman (1606/7-1680), Oxford Üniversitesi’nde yetişmiş bir şarkiyatçıydı. Seaman, 1628'de İstanbul'a gelerek, English Royal Society kurucu üyelerinin teşvikiyle İncil'i Türkçeye çevirmiştir. Bu çeviri Testamentum Novum Turcice Redditum adıyla 1666'da Oxford'da yayımlanmıştır (Hitzel 1995: 108-109). Bunun dışında İngiltere'de basılan ilk Türkçe gramer kitabı yine onun 1670'te basılan eseridir. William Seaman, söz konusu eserinde bazı kelimelerin Latin harfleriyle yazılışına yer vermiştir (Seaman 1670: 18).

Türkçe grameri üzerine bir eser veren diğer İngiliz, bir Levant Kumpanyası tüccarı olan Thomas Vaughan'dır. Vaughan, 1709'da yayımlanan Türkçeye dair gramer kitabında yer yer bazı metinlerin Latin harfleriyle Türkçe olarak nasıl yazıldı̆̆ına dair örnekler vermiştir. Tüccar oluşunun etkisiyle eserinde sık sık ticari hususlara değinmiştir. 
Görsel 12: Thomas Vaughan'ın Eserinden Bir Ticari Belge (Vaughan: 1709: 9).

\title{
Chap. I. Of Orthography. 9 \\ The Reading of the foregoing Temizuk, or Bill of Exchange.
}

\begin{abstract}
T Ege tahriry hurif bu dur ke Ingheliz Bazirganlerindain Sherman Vitkin nak̀ Bazirgandan ber vege karzy Sherai bing Uch yùz grulh eftikraz aịledim taiky del affi nezfe alté yúz slly grufhider meblaghy merkúmy hala Izmirde Gumroc Eminy olan Izetlu oglum Muftafy Aga Vuful Temifucdé otuz bir gún mururindés merkuming Izmirde Sherriky otan Pilkintón nam Bażirgañe Edá ve tellim ailemec uzra vajibul edá ve lazimul kazź dainim dur Vadeffy hululindè meblaghy merkum vege melhruhy uzrà tamamen edá ve teflim olunducte ifhbu Temifukimiz yeddindan akhiz ve befiz olúne. Tahríran $2 \mathrm{Nun}$ Senna 1 1og:

\section{El hakir el hadge Mahmet, Eminy Gumruc hala.}

\section{The Endorfement was thus:}

\section{Vemetturely Temizis: fe aZilkada Senina Tog:}

İngiltere'nin İstanbul elçisi Edward Wortley Montagu ile buraya gelen Lady Mary Wortley Montagu Türkçe öğrenmişti. Lady Montagu, Osmanlı topraklarında bulunduğu döneme dair anılarını mektupları vasıtasıyla kaydetmiştir. Mektupları, ölümünden sonra 1763 yılında kitaplaştırılmıştır. Montagu, 16 Mart 1718 tarihli mektubunda Küçük Bir İnci adlı bir şiirin Latin harfleriyle yazılışına yer vermiştir. 
Görsel 13: Lady Mary Wortley Montagu'nun Eserindeki Küçük Bir İnci Adlı Şiirin Bir Kısmı (Montagu 1861: 350-351)

\begin{tabular}{|c|c|}
\hline $\begin{array}{l}\text { Ingi, } \\
\text { Pearl, }\end{array}$ & $\begin{array}{l}\text { Sensin Guzelerin gingi } \\
\text { Fairest of the young. }\end{array}$ \\
\hline $\begin{array}{l}\text { Caremfil, } \\
\text { Clore, }\end{array}$ & $\begin{array}{l}\text { Caremfilsen cararen yók } \\
\text { Conge gulsum timarin yok } \\
\text { Benseny chok than severim } \\
\text { Senin benden, haberin yók. } \\
\text { You are as slewder as this clove! } \\
\text { Yow are an anbloscn rave! } \\
\text { I have long loved you, and you have not knoven it! }\end{array}$ \\
\hline $\begin{array}{l}\text { Pul, } \\
\text { Jonquil, }\end{array}$ & $\begin{array}{l}\text { Derdime derman bul } \\
\text { Have pity on sy patsion? }\end{array}$ \\
\hline $\begin{array}{l}\text { Kihat, } \\
\text { Poper, }\end{array}$ & $\begin{array}{l}\text { Birlerum sahat sahat } \\
\text { I faint every hour? }\end{array}$ \\
\hline $\begin{array}{l}\text { Ermus, } \\
\text { Pear, }\end{array}$ & $\begin{array}{l}\text { Ver bize bir umut } \\
\text { Give me sowe hope. }\end{array}$ \\
\hline $\begin{array}{l}\text { Jabun, } \\
\text { Soop, }\end{array}$ & $\begin{array}{l}\text { Derdinden oldum zabun } \\
\text { I am sick srith loce. }\end{array}$ \\
\hline $\begin{array}{l}\text { Chemur, } \\
\text { Coal, }\end{array}$ & $\begin{array}{l}\text { Ben oliyim size umur } \\
\text { May I die, and all wy zears be yours? }\end{array}$ \\
\hline $\begin{array}{l}\text { Gul, } \\
A \text { rose, }\end{array}$ & $\begin{array}{l}\text { Ben aglarum sen gul } \\
\text { Mey gos be pleased, and all your sornotse wive! }\end{array}$ \\
\hline
\end{tabular}

Lady Montagu'dan sonra Türk dili hakkında İngilizler tarafından pek çok araştırma yapılmıştır. Bunlardan William Burckhardt Barker, 1854 yılında basılan gramer kitabında yer yer bazı cümlelerin Latin harfleriyle yazımı üzerinde durmuştur (Barker 1854: 17). Latin harfleriyle Türkçe yazanların adları, eserlerinin yazılma/basılma yılları ve bu şahısların milliyetleri, topluca bir değerlendirmeye yardımcı olması için aşağıda tablo hâlinde verilmiştir: 


\section{Tarihte Latin Harfleriyle Türkçe Metin Yazan Batılılar}

\begin{tabular}{|c|c|c|c|}
\hline \multicolumn{2}{|c|}{ Eser Sahibinin Adı } & \multirow{2}{*}{$\begin{array}{l}\text { Eserin Yazım/Basım Yılı } \\
1460 \\
\end{array}$} & \multirow{2}{*}{\begin{tabular}{|l|} 
Osmanlı Topraklarında \\
Bulunma / Türkçe Öğrenme \\
Nedeni
\end{tabular}} \\
\hline 11 & Johannes Schilberger & & \\
\hline 2 & Filippo Argentini & 1533 & Floransa konsolosluk görevlisi \\
\hline 3 & Bartholemaeus Georgiević & 1558 & Macar savaş esiri \\
\hline 4 & Michele Membré & 1567 & Venedikli tercüman \\
\hline 5 & Guillaume Postel & 1575 & $\begin{array}{l}\text { Fransız bilim adamı, elçilik } \\
\text { görevlisi }\end{array}$ \\
\hline 6 & Hieronymus Megiser & 1612 & Alman bilim adamı \\
\hline 7 & Pietro Della Valle & 1615 (çalışma defteri) & Romalı seyyah \\
\hline 8 & Reinhold Lubenau & 1628 (yazma eser) & Habsburg elçisi \\
\hline 9 & Giovan Battista Montalbano & 1622-1632(tahminen) & Bolognalı seyyah \\
\hline 110 & André Du Ryer & 1630 & Fransız elçilik görevlisi \\
\hline 111 & Giovanni Molino & 1641 & Venedikli tercüman \\
\hline 112 & Albertus Boboivus/Santuri Ali & $\begin{array}{l}\text { Ufki Bey 1650'ler } \\
\text { (tahminen) }\end{array}$ & Leh asılllı Osmanlı tercümanı \\
\hline 113 & Clausier de Loir & 1654 & Fransiz seyyah \\
\hline 114 & William Seaman & 1670 & İngiliz şarkiyatç1/elçilik görevlisi \\
\hline 115 & Jakab Harsányi-Nagy & 1672 & Erdel maslahatgüzarı \\
\hline 116 & Francisci Mesgnien Meninski & 1680 & $\begin{array}{l}\text { Leh asıllı bilim adamı / } \\
\text { Habsburg elçisi }\end{array}$ \\
\hline 117 & Giovanni Battista Donado & 1688 & Venedikli elçi \\
\hline 118 & Giovanni Battista Podestà & 1692 & Habsburg elçisi \\
\hline 119 & Thomas Vaughan & 1709 & $\begin{array}{l}\text { İngiliz Levant kumpanyası } \\
\text { tüccarı }\end{array}$ \\
\hline 220 & Jean Baptiste D. Holderman & 1730 & Fransız peder (din adamı) \\
\hline 221 & Johannis Christiani Clodii & 1730 & Alman dil bilimci? \\
\hline 222 & Luigi Fernando Comte de Marsigli & 1732 & Venedik askerî ataşesi \\
\hline 223 & Lady Mary Wortley Montagu & 1763 & İngiliz elçisinin eşi \\
\hline 224 & Bernardino Pianzola & 1777 & $\begin{array}{l}\text { İtalyan şehir cumhuriyeti, } \\
\text { misyoner, peder (din adamı) }\end{array}$ \\
\hline 225 & Pierre François Viguier & 1790 & Fransız peder (din adamı) \\
\hline 226 & Cosimo Comidas de Carbognano & 1794 & $\begin{array}{l}\text { Ermeni asılll, Napoli elçiliği } \\
\text { dil oğlanı - İspanya elçiliği } \\
\text { tercümanı }\end{array}$ \\
\hline 227 & Antoine-Ignace Melling & 1784-1802 (mektuplar) & Fransiz seyyah, mimar, ressam \\
\hline 228 & Heinrich Julius Klaproth & 1820 & Alman bilim adamı \\
\hline 229 & Xavier Bianchi & 1843 & Fransız elçiliği dil oğlanı \\
\hline 330 & William Burckhardt Barker & 1854 & İngiliz bilim adamı \\
\hline 331 & P. Samuel Catergian & 1855 & Ermeni asıllı Venedikli keşiş \\
\hline 332 & Nassif Mallouf & 1862 & $\begin{array}{l}\text { Fransız tercüman, elçi, bilim } \\
\text { adamı }\end{array}$ \\
\hline
\end{tabular}




\section{SONUÇ}

Matbaanın icadı ve yaygınlaşması, bilginin daha geniş kitlelere ulaşmasını sağlamıştır. Böylece Avrupa'da Latince dışında diller de önem kazanmaya başlamış, Latin harfli Türkçe eserlerin basımıyla daha çok insan Türkçe öğrenmiştir. Bunun sonucunda çok sayıda kişi Latin harfli Türkçe metin yazmıştır. Codex Cumanicus'tan sonra Latin harfleriyle yazılmış ilk Türkçe ifadeler, Johannes Schiltberger adlı bir Alman'ın kaleme aldığı esaret anılarında geçmektedir. 15. Yüzyıldan başlayarak, Osmanlı Devleti'nin yıkılışına kadar, Avrupada çeşitli statülere mensup Alman, Fransız, Macar, Leh, İngiliz; Venedikli, Napolili, Bolognalı tarafından bazısı kısmen bazısı tamamen Türkçe ifadelerin yer aldığ Latin harfli eserler vücuda getirilmiştir. Bunları yazan 32 kişiden 2'si esir, 13'ü diplomatik misyon çalışanı ya da çalışanları ile irtibatlı şahıs, 4'ü bilim adamı, 4'ü din adamı, 4'ü seyyah, 1'i tüccar ve 4'ü de hem bilim adamı hem yabancı misyon çalışanıdır.

Codex Cumanicus dışındaki eserlerin yazım/basım tarihlerine bakıldığında, bunların XV.-XIX. yüzyıllar arasında yayınlandıkları görülür. Eserlerin yazılış tarihleri esas alınarak bir sınıflandırma yapmak gerekirse, bu tasnif, erken modern dönem ve modern dönem şeklinde olabilir. Bu ayrıma göre; 32 eserden 22'sinin erken modern dönemde, diğerlerinin de modern dönemde yazıldığı anlaşılmaktadır. Erken modern dönem, Osmanlı Devleti'nin dünyanın büyük bölümüne hükmettiği, gücünün zirvede olduğu bir devre tekabül eder. Dolayısıyla bu dönemde Türkçe bilmek pek çok yönden avantaj sağlamaktaydı. Türkçe yazan batılılara dair tablodan da anlaşılacağı üzere, bunlar Osmanlı Devleti ile ticari, siyasi ve içtimai münasebetleri bulunan toplumlara mensup idiler.

Türkçe öğrenme ve Latin harfleriyle Türkçe yazma hususunda İtalyan şehir cumhuriyetleri tebaasına mensup olanların sayısının diğer topluluklara oranla oldukça fazla olduğu görülmektedir. Bu durum, söz konusu şehir cumhuriyetlerinin ticari, siyasi, içtimai çıarlarını koruma, geliştirme gayretleriyle izah edilebilir. Erken modern dönemin sonu hem Osmanlı Devleti hem de söz konusu şehir cumhuriyetlerinin güç kaybına uğradığ 1 bir zaman dilimine tekabül eder. Her ne kadar XVIII. yüzyılda Turquerie adı verilen moda akımından bahsedilebilse de yüzyılın sonu aynı zamanda bu moda akımının da sonunu getirmiştir. Dolayısıyla Osmanlı Devleti'nin güç kaybına bağlı olarak Türkçe öğrenip yazma eğiliminde olan Avrupalıların sayısında da azalma meydana gelmiştir. Modern dönemde Türkçenin daha ziyade bilim adamları için bir çalışma konusu hâline geldiği anlaşılmaktadır. Yukarıda adları zikredilen şahıslardan üçü, din adamı kimliğine sahiptir. 
Bunların Osmanlı topraklarında Hristiyanlığı yaymak adına misyonerlik faaliyeti içerisinde oldukları kuşkusuzdur. Bunlar Türkçe öğrenmeyi, hedef kitlelerine ulaşmada bir araç olarak görmüşlerdir.

\section{Kaynaklar}

Adamović, Milan (2009). 16. Yüzynl Türkçesi: Floransalı Filippo Argenti’nin Notlarına Göre (1533), Çev.: Aziz Merhan, Ankara: Türk Dil Kurumu Yayınlar1.

Alarslan, Burcu (2005). “Türk İmajının Görsel Yansımaları”, Dünya’da Türk İmgesi, Ed.: Özlem Kumrular, İstanbul: Kitabevi Yayınları.

Akar, Ali (2014). “Kuzey Bozkırlarından Ön Asyàya Beş Bin Yıllık Serüven: Türk Dilinin Tarih İçindeki Yolculuğu”, Türkler-Uzun Bir Serüvenden Kısa Notlar, Ed.: Reha Bilge, İstanbul: Arvana Yayınları.

Arıkan, Zeki (1984). "Guillaume Postel ve "De la République des Turcs", Tarih İncelemeleri Dergisi II, İzmir.

Balta, Evangelia (2014). Gerçi Rum İsek de Rumca Bilmez Türkşe Söyleriz, Karamanlılar ve Karamanlıca Edebiyat Üzerine Araştırmalar, Haz.: M. Fatih Uslu-Fatih Altuğ, İstanbul: İş Bankası Kültür Yayınları.

Barker, William Burckhardt (1854). A Practical Grammar of the Turkish Language: With Dialogues and Vocabulary, London.

Bottéro, Jean (2012). Mezopotamya Yazı, Akıl ve Tanrılar, çev. Mehmet Emin Özcan, Ayten Er, Ankara: Dost Yayınları.

Bevilacqua, Alexander-Helen Pfeifer (2013). “Turquerie: Culture in Motion, 1650-1750”, Past \& Present, CCXXI/1.

Bianchi, Thomas Xavier (1843). Dictionnaire Français-Turc I, Paris.

Bloom, Jonathan M. (2003). Kâğgda İslenen Uygarlık Kâğıdın Taribi ve İslâm Dünyasına Etkisi, Çev.: Zülal Kılıç, İstanbul: Kitap Yayınevi.

Boboivus, Albertus; /Santuri Ali Ufki Bey (2002). Albertus Boboivus ya da Santuri Ali Ufki Bey'in Anıları, Topkapı Sarayı'nda Yaşam, Çev.: Ali Berktay, İstanbul: Kitap Yayınevi.

; Mecmua ou allbum de poésies turques, la plupart sans aucun nom d'auteur, quelques-unes de Necâtî, dans les marges duquel, ainsi que sur les pages restées en blanc, un possesseur de ce livre a écrit des extraits de la Jérusalem délivrée, des notes médicales ou botaniques, en 
italien, de la musique italienne et allemande, et la notation, quelquefois avec transcription, de chansons turques, par 'Ali Beg Bobowski, dit'Ali Ufkî, Bibliothèque Nationale de France, Turc 292.

Breydenbach, Bernhard von (1486). Prefatio in Opus Transmarine Peregrinationis ad Venerandu[m] et Gloriosum Sepulcru[m] Dominicu[m] in Iherusale $[m]$, Yale University Library Beinecke Rare Book and Manuscript Library, Object ID: 2057980, Mainz.

Burman, Thomas E. (2013). Latince Kur'an Cevirileri 1140-1560, Çev.: Nisan Alıc1, İstanbul: İthaki Yayınları.

Carbognano, Cosimo Comidas (1993). 18. Yüzyılın Sonunda İstanbul, Çev.: Erendiz Özbayoğlu, İstanbul: Eren Yayınları.

(1794). Primi Principi Della Grammatica Turca, ad uso Dei Missionari Apostilici di Constantinopoli, Roma.

Catergian, P. Samuel (1855). Guide de Conversation Turc-Français-Allemand, Vienne.

Casale, Giancarlo (2014). "Geçmişi Görmek”, Osmanlı Sarayında Tarih Yazımı, Çev.: Mete Tunçay, drl. H. Erdem Çıpa-Emine Fetvacı, İstanbul: Tarih Vakfi Yurt Yayınları.

Codex Cumanicus Bibliothecae ad Templum Divi Marci Venetiarum (1880), Ed. Comes Géza Kuun, Scient Academi/e Hung., Budapestini. [Türkçesi: Codex Cumanicus (2015), Haz.: Mustafa Argunşah-Galib Güner, İstanbul: Kesit Yayınlar1.]

Clodii, Johannis Christiani (1730). Compendiosum Lexicon Latino-TurcicoGermanicum: In Quo Non Solum Voces Et Phrases Usitatae Continentur, Sed Etiam Illarum Lectio, Adjectis Ubique Observationibus Variis, Ad Statum Ecclesiasticum, Politicum, Et Militarem Pertinentibus: Cum Prefatione De Lingua Et Litteratura Turcarum, Corruptisque Vulgari Pronuntiatione, Nominibus Ministrorum Aulae Turcicae, Accesit Triplex Index. Grammatica Turcica, I, II, Lipsia [Leipzig].

Dilaçar, Agop (1970). “1612'de Avrupa'da Yayımlanan İlk Türkçe Gramerinin Özellikleri”, Türk Dili Araştırmaları Yıllığı Belleten, Ankara: Türk Dil Kurumu Yayınlar1. Marsigli, Luigi Fernando Comte de (1732). L'Etat Militaire de L'empire Ottoman, Ses Progrès et sa Décadence II, Hague Amsterdam.

Donado, Giovanni Battista (1688). Della Letteratvra de' Turchi. Osservationi fatte da Gio: Battista Donado senator veneto, fü bailo in Costantinopoli, Venetia. 
Dursteler, Eric R. (2012). İstanbul'daki Venedikliler Yeniçă̆ Başlarında Akdeniz'de Millet, Kimlik ve Bir Arada Varoluş, Çev.: Taciser Ulaş Belge, İstanbul: Türkiye İş Bankası Kültür Yayınları.

Duru, Necip Fazıl - Riza Duru (2010). “La Croix Paitis'in 1665’te Latin Harfleriyle Yazdığı Türkçe Bir Gazel”, Uluslararası Sosyal Araștırmalar Dergisi III/11, Ordu.

Erden, Yahya (1995). “Avrupa'da Arap Harfleriyle Basılan Arapça ve Türkçe Kitaplar (1514-1700)”, Kebikeç I/2, Ankara.

Febvre, Lucien -Henri Jean Martin (2000). Kitabın Doğuşu, Çev.: Gül Batuş, İstanbul: Avcıol Basım Yayın.

Fischer, Steven Roger (2003). A History of Reading, Reaktion Books, London.

Gallotta, Aldo (1986). “Latin Harfleri ile Yazılmış Bir Kaç Osmanlı Atasözü”, İstanbul Üniversitesi Türk Dili ve Edebiyatı Dergisi XXIV, İstanbul.

Georgieuiz, Bartholomao (1558). De re Turcarvm Moribus Epitome, Basım yeri yok.

Giacomo E. Carretto (1992). Akdeniz'de Türkler, Çev.: Durdu KundakçıGülbende Kuray, Ankara: Türk Tarih Kurumu Yayınları.

Guillaume Postel (1575). Des Histoires Orientales et Principalement des Turkes ou Turchikes et Schitiques ou Tartaresques et Aultres qui en Sont Descendues, Oeuvre Pour la Tierce Fois Augmenté, Paris.

Harsany, Jacobus Nagy De (1672). Colloquia Familiaria Turcico-Latina: Seu Status Turcicus Loquens, Branderburg. [Almancası: György Harzai (1973). Das Osmanisch-Türkische im XVII. Jahrhundert: Untersuchungen an den Transkriptionstexten von Jakab Nagy de Harsány, Akademiai Kiado, Budapest.]

Hazai, Georgy (1971). “Jakab Harsányi-Nagy'in Latin Harfleriyle Yazılmıs Türkçe Metinleri”, Türk Dili Araștırmaları Yıllığı Belleten 338, Ankara: Türk Dil Kurumu Yayınları.

(1967). “Kiril Harfleriyle Yazılı Bir Türkçe Metin Üzerine”, Türk Dili Araştırmaları Yıllığı Belleten 255, Ankara: Türk Dil Kurumu Yayınları.

Hitzel, Frédéric (1995). Enfants de Langue et Drogmans/Dil Oğlanları ve Tercumanlar, Çev.: Mehmet Sert, İstanbul: Yapı Kredi Yayınları.

Holderman, Jean Baptiste D. (1730). Grammaire Turque, ou Méthode Courte 
et Facile Pour Apprendre la Langue Turque: Avec un Recueil des Noms, des Verbes et des Manières de Parler les Plus Necessaires a Sçavoir, Avec Plusieus Dialogues Familiers, Constantinople.

Klaproth, Heinrich Julius (1820). Abhandlung über die Sprache und Schrift der Uiguren, Paris.

Kumrular, Özlem (2012). “16. Yüzy1lda Akdeniz'de 'Türk' İmgesinin Yaratılması: Antipropagandaya Karşı Özdüşünüm”, Hayallerdeki “Türk”, Ed.: Božidar Jezernik, İstanbul: Kitap Yayınevi.

Loir, Clausier de, (2016). De Loir Seyahatnamesi IV. Murad Döneminde Bir Fransız Seyyahın Maceraları, Çev. Mustafa Daş, İstanbul: Yeditepe Yayınlar1.

Lubenau, Reinhold (2012). Reinhold Lubenau Seyahatnamesi (Osmanl Ülkesinde, 15871589), I, Çev.: Türkis Noyan, ed. Stefanos Yerasimos, İstanbul: Kitap Yayınevi.

Luigi Bassano (1545). I Costumi et i Modi Particolari de la Vita de Turchi, Rome. [Türkçesi:

Luigi Bassano (2015) Kanuni Dönemi Osmanl Imparatorluğu’nda Gündelik Hayat, Çev.: Sibel Cangi, İstanbul: Yeditepe Yayınevi.]

Mallouf, Nassif (1856). Dictionnaire Français-Turc, Avec La Prononciation Figurée, Paris.

Manguel, Alberto (2010). Okumanın Taribi, Çev. Füsun Elioğlu, İstanbul: Yap1 Kredi Yayınlar1.

Megiser, Hieronymus (1612). Institutionum Linguae Turcicae Libri Quatuor, Leipzig.

Melling, Antoine-Ignace (1819). Voyage Pittoresque de Constantinople et des Rives du Bosphore, Paris [Türkçesi-İngilizcesi: Antoine-Ignace Melling, Istanbul ve Boğaz Kiynlarına Pitoresk Seyahat (A Picturesque Voyage to Constantinople and the Shores of the Bosphorus- Voyage Pittoresque de Constantinople et des Rives du Bosphore), ed. Rezan Benatar, trans. İvrin Cemil Schick, çev. Ece Zerman, İstanbul, Denizler Kitabevi,2012.]

Meral, Yasin (2016). İbrabim Müteferrika Öncesi İstanbul'da Yahudi Matbuatı (1493-1729), Ankara: Divan Kitap.

Meninski, Francisci Mesgnien (1680). Thesaurus Linguarum Orientalium Turcicae, Arabicae, Persicae, Vienne [Türkçesi: Franciscus à Mesgnien Meninski, Thesaurus Linguarum Orientalium Turcicae - Arabicae - 
Persicae $=$ Lexicon Turcico - Arabico-Persicum/ Sözlük, Türk Dili, Türkçe, Dilbilim, Türk Dilleri, I, II, III, IV, V, VI, İstanbul, Simurg Yayınları, 2000.]

Meyer, Eve R. (1974). "Turquerie and Eighteenth-Century Music", Eighteenth-Century Studies, VII/4.

Molino, Giovanni (1641). Dittionario Della Lingua Italiana, Turchesca, Roma.

Montagu, Lady Mary Wortley (1861). The Letters and Works of Lady Mary Wortley Montagu, I, ed. Lord Wharncliffe, London. [Türkçesi: Lady Mary Montagu (2014). Şark'tan Mektuplar, Haz.: Selçuk Ünlü, Konya: Palet Yayınları.]

[Mour, Jean Baptiste Van] (1714), Recueil de Cent Estampes Representant du Differentes Nations du Levant, tirées d'après nature en 1707 et 1708, Ed.: De M. De Ferriol, Paris.

Nasir al-Din al-Tusi (1594). Kitab Tabrir Usul li-Uqlidis Min Ta'lif Khrwaja Nasir al-Din alTusi. Euclidis Elementorum Geometricorum Libri Tredecim. Ex Traditione Doctissimi Nasiridini Tusini. Nunc Primum Arabice Impressi, (in Typographia Medicea), Romae.

Nicolay, de Nicolas (2014). Mubtęsem Süleyman'ın İmparatorluğunda, ed. Marie-Christine Gomez-Geraud, Stefanos Yerasimos, Çev.: Şirin Tekeli-Menekşe Tokyay, İstanbul: Kitap Yayınevi.

Offenberg, Adri K. (1996). "The printing history of the Constantinople Hebrew İncunable of 1493: a Mediterranean Voyage of Discovery", The British Library Journal XXII.

Pamukciyan, Kevork (2002). Ermeni Kaynaklarından Tarihe Katkılar IIErmeni Harfi Türkçe Metinler, Haz. Osman Köker, İstanbul: Aras Yayıncilik.

(2003). Ermeni Kaynaklarından Taribe Katkılar-IV, Biyografileriyle Ermeniler, İstanbul: Aras Yayınları.

Pedani, Maria Pia (2015). Doğu’nun Kapısı Venedik, Çev. Gökçen Karaca Şahin, İstanbul: Küre Yayınları.

Pedersen, Johannes (2012). İslam Dünyasında Kitabın Taribi, Çev.: Mustafa Macit Karagözoğlu, İstanbul: Klasik Yayınları.

Pektaş, Nil (2015). “The Begginings of Printing in Ottoman Capital: Book Production and Circulation in Early Modern İstanbul", Osmanl Bilimi Araștırmaları XVI/2, İstanbul. 
Perot, Jaques - Frédéric Hitzel-Robert Anhegger (2001). Hatice Sultan ile Melling Kalfa Mektuplar, Çev.: Ela Gültekin, İstanbul: Tarih Vakfı Yurt Yayınları.

Pianzola, Bernardino (1789). Dizionario Grammatiche, E Dialoghi Per Apprendere Le Lingue Italiana, Greca-Volgare, e Turca, e Varie Scienze, IV, Padova.

(1777). Kyssa Christoneaghan Vartabedutiunun Muktaseri Stambolda ve Edrinede Surp Andonun Kilisesinde P. Bernardinos Pianzola Öjrettijine Göre, Podova.

Podestà, Giovanni Battista (1677). Assertiones De Principiis Substantialibus, Accidentalibus Proximis \& Remotis, Diversisque Differentiis Linguarum: de Turcica, Arabica E Persica in Communi \& Particulari, de in Fluxu Arabicae in Persicam, Utriusque in Turcicam, Deque Eorum Arithmetica, Viennae, 1669; Dissertatio Academica Continens Specimen Triennalis Profectûs in Linguis Orientalibus, Arabica Nempè, Persica et Turcica, Viennae. (1692).Cursus Grammaticalis Linguarum Orientalium, Arabicae Scilicet, Persicae et Turcicae I, Viennae.

Schiltberger, [Jo]Han[ne]s; Reisebuch, Universitätsbibliothek Heidelberg, Cod. Pal. Germ.

216. [Türkçesi: Schilberger, Johannes (1997). Türkler ve Tatarlar Arasında (1394-1427), Çev.: Turgut Akpınar, İstanbul: İletişim Yayınlar1.]

Seaman, William (1670). Grammatica Linguce Turcice, in Quinque Partes Distributa, Basım yeri yok.

Speelman, Rainero (2002). "Uno sconosciuto 'West-Östlicher Divan' di Pietro Della Valle” Electronic Journal of Oriental Studies, V, Utrecht.

Şakiroğlu, Mahmut H. (1992). "Balyos”, İslam Ansiklopedisi V, İstanbul: Türkiye Diyanet Vakfı Yayınları.

(1992). "Alessio Bombaci", İslam Ansiklopedisi VI, İstanbul: Türkiye Diyanet Vakfı Yayınları.

(1995). "Batı Ülkelerinde Yapılan Arap Harfli Basımın Kaynağı ve Etkisi”, Kebikeç I/2, Ankara.

Tekin, Talat (1997). Tarib Boyunca Türkşenin Yazımı, İstanbul: Simurg Yayınları. 
Teotig (Teotoros Lapçinciyan) (2012). Baskı ve Harf Ermeni Matbaacılık Taribi Ermeni Alfabesinin 1600. ve Ermeni Matbaacıliğının 500. Yılında Dib u Dar, Çev.: Sirvart Malhasyan-Arlet İncidüzen, İstanbul: Bir Zamanlar Yayınc1lik.

Toderini, Giambattista (1787). Letteratura Turchesta, I, II, III, Venezia, [Eserin kısmen yapilmı̧̧ Türkçe çevirisi: Giambattista Toderini (2012). Türklerin Yazılı Kültürü (Türklerin Edebiyatı), Çev. Ali Berktay, İstanbul: Yap1 Kredi Yayınlar1.]

Toparlı, Recep ve Hanifi Topal, Recep Karaatlı (2007). Kip̧̧ak Türkçesi Sözlüğ̈̈, Ankara: Türk Dil Kurumu Yayınları.

Türkiye Büyük Millet Meclisi Zabıt Ceridesi, Devre 3, İctima 2, V, 1 Teşrin-i sâni 1928, ss. 1-13.

Türkiye Cumburiyeti Resmî Gazetesi, 3 Teşrîn-i evvel 1928, 1030, Kanun nu.: 1353, ss. 5998-6003.

Vallé, Pietro Della (2011). Osmanl Topraklarında Bir İtalyan Gezgin Pietro Della Valle’nin Çalı̧̧ma Defteri, Haz. Nevin Özkan, Raniero Speelman, Mustafa Çiçekler, Ankara: Türk Dil Kurumu Yayınları.

(1745). Voyages de Pietro de Vallé Gentilhome Romain Dans la Turquie, l'Egypte, la Palestine, la Perse, les Indes Orientales, E' autres lieux, I, Nouvelle Edition, Paris.

Vaughan, Thomas (1709). Grammar of The Turkish Language, London.

Verhaaren, Christine Isom (2015). Kâfirle Itttifak, 16. Yüzyıl Osmanlı-Fransız Anlaşması, Çev. Ayla Ortaç, İstanbul: Kitap Yayınevi.

Viguier, Pierre François (1790). Élémens De La Langue Turque, Ou Tables Analytiques De La Langue Turque Usuelle, Avec Leur Développement, Constantinople.

Williams, Haydn (2015). Turquerie 18. yüzyılda Avrupa'da Türk Modası, Çev. Nureddin Elhüseyni, İstanbul: Yap1 Kredi Yayınları.

Wood, Alfred C. (2013). Levant Kumpanyası Taribi, Çev. Çiğdem Erkal İpek, Ankara: Doğu Batı Yayınları. 


\section{ABSTRACT \\ Works Written in Turkish Using the Latin Characters during the Ottoman Era}

It is known that there existed a feeling of fear towards the Ottomans among the European societies who had economic, political and military relationships with the Ottoman state in the early modern era (14501750). This fear, which derived from failure to cope with the Turks in the military field, evolved into curiosity about the Ottomans from the late 16th century on. This took the form of imitating the Ottomans in clothing, music and art. Desire to learn Turkish is one of the natural reflections of this. It is interesting that Turkish was adopted as a lingua franca, or a common language. This study will dwell on texts written by Westerns in Turkish using the Latin characters but no attempt will be made to explain how the texts can be used language studies. The effects of the fear from Turks and the movement of Turquerie, which was born out of this, on interest in learning Turkish in Europe and the results if this will be discussed. The dynamics that determined learning and writing in Turkish will be revealed on the basis of Turkish texts and relevant works. The nationalities of the text writers, their reasons for learning Turkish and the dates when the works were written were taken into consideration in the assessment. In addition, mention was also made of the effects of the printing press on learning non-Latin languages, including Turkish. The study is expected to reveal, with its fundamental reasons, the perception of Turkish language in the early modern era.

Keywords: Turkish, Latin characters, printing press, early modern era, lingua franca 